\title{
A Highly Efficient and Stable Photocatalyst; N-Doped ZnO/CNT Composite Thin Film Synthesized via Simple Sol-Gel Drop Coating Method
}

\author{
Md Elias 1,2 ${ }^{\mathbb{D}}$, Md Nizam Uddin 1,*, Joyanta Kumar Saha ${ }^{2} \mathbb{D}$, Md Awlad Hossain ${ }^{2}$, Dali R. Sarker ${ }^{1}$, Sonia Akter ${ }^{1}$, \\ Iqbal A. Siddiquey ${ }^{1}$ and Jamal Uddin ${ }^{3}(\mathbb{D}$ \\ 1 Department of Chemistry, Shahjalal University of Science and Technology, Sylhet 3114, Bangladesh; \\ elias_chesust@yahoo.com (M.E.); daliranisarker.sust@gmail.com (D.R.S.); sonia_chesust@yahoo.com (S.A.); \\ iqbal_siddiquey@yahoo.com (I.A.S.) \\ 2 Department of Chemistry, Jagannath University, Dhaka 1100, Bangladesh; joys643@yahoo.com (J.K.S.); \\ awlad1975@yahoo.com (M.A.H.) \\ 3 Center for Nanotechnology, Department of Natural Sciences, Coppin State University, 2500 W. North Ave, \\ Baltimore, MD 21216, USA; juddin@coppin.edu \\ * Correspondence: nizam-che@sust.edu or nizam3472@yahoo.com
}

check for

updates

Citation: Elias, M.; Uddin, M.N.; Saha, J.K.; Hossain, M.A.; Sarker, D.R.; Akter, S.; Siddiquey, I.A.; Uddin, J. A Highly Efficient and Stable Photocatalyst; N-doped ZnO/CNT Composite Thin Film Synthesized via Simple Sol-Gel Drop Coating Method. Molecules 2021, 26, 1470. https:// doi.org/10.3390/molecules26051470

Academic Editor: Wanhong Ma

Received: 2 February 2021

Accepted: 4 March 2021

Published: 8 March 2021

Publisher's Note: MDPI stays neutral with regard to jurisdictional claims in published maps and institutional affiliations.

Copyright: (c) 2021 by the authors. Licensee MDPI, Basel, Switzerland. This article is an open access article distributed under the terms and conditions of the Creative Commons Attribution (CC BY) license (https:/ / creativecommons.org/licenses/by/ $4.0 /)$.

\begin{abstract}
The thin film of N-doped $\mathrm{ZnO} / \mathrm{CNT}$ nanocomposite was successfully fabricated on soda lime glass substrate by a simple sol-gel drop-coating method. The structural, morphological, chemical, and optical properties of as prepared samples were characterized by a variety of tools such as Xray Diffraction (XRD), Field Emission Scanning Electron Microscopy (FE-SEM), Fourier Transform Infrared spectroscopy (FT-IR), and UV-visible spectroscopy. The hexagonal crystalline structure was confirmed from XRD measurement without any other impurity phase detection in samples. The $\mathrm{N}$-doped $\mathrm{ZnO} / \mathrm{CNT}$ composite showed excellent photo-catalytic activity towards cationic methylene blue (MB) dye degradation with $100 \%$ removal rate under UV light irradiation as compared to $\mathrm{N}$-doped $\mathrm{ZnO}(65 \%)$ and pure $\mathrm{ZnO}(47.36 \%)$. The convincing performance has also been observed for the case of visible light irradiation. The enhancement of that photocatalytic activity might be due to narrowing the band gap as well as the reduction of electron-hole pair recombination in $\mathrm{ZnO}$ matrix with the incorporation of dopant nitrogen and CNT. It is assumed from the obtained results that N-doped ZnO/CNT nanocomposite thin film can be employed as an economically achievable and ecofriendly method to degrade dye with UV and visible light irradiation. Additionally, density functional theory (DFT) calculations were applied to explore the effect of $\mathrm{N}$-doping on electronic structure of $\mathrm{ZnO}$. The computational study has supported the experimental results of significant band gap contraction, which leads to the maximum absorption towards higher wavelength and no appreciable change of lattice parameters after doping. A conceivable photocatalytic mechanism of $\mathrm{N}$-doped $\mathrm{ZnO} / \mathrm{CNT}$ nanocomposite has been proposed as well.
\end{abstract}

Keywords: photocatalysis; thin film; DFT; photodegradation; lattice parameters; drop-coating

\section{Introduction}

Organic pollutants like colored dyes, antibiotics, and colorless organic matters in aquatic environments are now considered as threats for the natural environment and human health [1-3]. Especially, colored dyes are mainly heterocyclic organic compounds, which have $\mathrm{N}=\mathrm{N}$ bonds and sulfonic group in their molecular structure. These dyes are extensively used in the various industries such as the textile industry. The disposal of dyes into water bodies can constitute widespread damages to human health, aquatic life, and the food chain because of its noxious effects [4-6]. The dyes are highly colored toxic organic compounds, which can affect the photosynthesis action of entire ecosystem by reducing sunlight penetration and dissolve oxygen $[7,8]$. This indicates the necessity of treatment of water containing dye before disposal into the environment. A wide number of dye 
treatment methods such as coagulation [9], chemical oxidation [10], adsorption [11], reverse osmosis [12], ion exchange [13], ozonization [14], electrolysis [15], biodegradation [16], and photocatalytic degradation [17], etc. have been implemented to complete mineralization of dye.

Among these methods, heterogeneous photocatalysis by semiconductor photocatalysts is well known as the advanced oxidation process employed as a green and sustainable method for the detoxification of wide range organic dyes and inorganic pollutants into environmentally benign products at ambient temperatures and pressures [18]. This removal method is very simple as well as free from any involvement of toxic, hazardous, and expensive environmentally malignant chemicals [19].

Zinc Oxide $(\mathrm{ZnO})$ has been regarded as a remarkable broad band gap semiconductor of $3.37 \mathrm{eV}$ with substantial excitation binding energy (60 meV). In addition, $\mathrm{ZnO}$ based heterogeneous photocatalysis has been widely used for waste water treatment due to their outstanding photocatalytic property, abundance in nature, low cost, high chemical stability, appropriate optical band gap, low toxicity, and environmental sustainability [20-22]. Furthermore, some researchers reported that $\mathrm{ZnO}$ exhibited higher photocatalytic performance than $\mathrm{TiO}_{2}[23,24]$. However, the $\mathrm{ZnO}$ photocatalyst still shows low photocatalytic activity because of several problems such as low photon utilization efficiency, fast recombination rate of charge carriers and narrow spectrum range due to wide band gap, etc. [25].

As a result, further modification of $\mathrm{ZnO}$ is indeed needed to improve the photocatalytic efficiency [26,27]. Doping with metals and non-metals into $\mathrm{ZnO}$ semiconductor has been used to modify the light absorption towards the visible region or to improve the photocatalytic efficiency. In particular, dopant nitrogen has been attracting much attention because of its abundance, low material toxicity, compatible size, low ionization energy, and ease of handling $[28,29]$. Zong et al. showed that $\mathrm{N}$-doped $\mathrm{ZnO}$ bundle-like nanoparticles demonstrated a higher photocatalytic oxidation activity under visible light irradiation [28]. Qin et al. reported that heterostructure $\mathrm{N}$-doped $\mathrm{ZnO}$ exhibited better photocatalytic degradation towards humic acids compared to pure $\mathrm{ZnO}$ thin film [30]. Moreover, many researchers have studied extensively on nitrogen doped various semiconductor photocatalysts such as $\mathrm{TiO}_{2}, \mathrm{SnO}_{2}, \mathrm{CdS}$, etc. to improve their photocatalytic activity $[11,29,31-34]$. It can reduce the band gap and also decrease the rate of electron-hole pair recombination.

Another approach of improving the photocatalytic efficiency of $\mathrm{ZnO}$ semiconductor photocatalyst involves the attachment of carbon nanotubes(CNTs) [35]. CNTs have some remarkable advantages, properties like superior chemical stability, strong adsorptive ability, and excellent electronic and conductive properties [26]. Additionally, the large electron storage capacity of CNTs improves the photocatalytic efficiency by accepting the photogenerated electron from the conduction band of $\mathrm{ZnO}$ at the heterojunction interface of $\mathrm{ZnO}$ and CNT [36]. From the several studies, it is concluded that polar groups on the surface of CNT due to functionalization provide a significant way to enhance the photocatalytic efficiency of the nanocomposite thin film photocatalysts [36,37]. Zhu et al. prepared ZnO-coated multi-walled CNT composites via a sol process and observed improved photocatalytic degradation of methyl orange (MO) dye ( 98\%) than pure $\mathrm{ZnO}$ [38]. Azqhandi et al. fabricated $\mathrm{Cd}$-doped $\mathrm{ZnO} / \mathrm{CNT}$ nanocomposites by a microwave assisted hydrothermal method and investigated their photocatalytic behavior under UV light irradiation and adsorption properties [39].

Despite the above significant advancement, numerous issues related to the powder form photocatalysts and fabrication techniques remain to be addressed. For example, the filtration process is necessary before reuse and recycles, although thin film forms of those materials is the key to minimizing the issue. Moreover, many thin film fabrication methods such as dip coating, chemical vapor deposition, spray-pyrolysis, electro-deposition, chemical bath deposition, and other methods have been used in the last few decades [40]. The newly proposed drop coating thin film fabrication technique is very easy, low cost, as well as the amount of materials for each sample could be controlled at a molecular level. Very recently, we have reported the sol-gel drop coating synthesis of Ce-doped ZnO/CNT 
composite thin film and found the enhanced visible light photodegradation over MB dye. Despite there being a huge number of works on composite photocatalysts, no work has been reported on $\mathrm{N}$-doped $\mathrm{ZnO} / \mathrm{CNT}$ composite thin film.

In this research, the $\mathrm{N}$-doped $\mathrm{ZnO} / \mathrm{CNT}$ thin film on glass substrate has been fabricated by a simple sol-gel drop coating method. The influence of dopant nitrogen and sensitizer CNTs on the structural behavior of the ZnO was analyzed by XRD, FESEM, FT-IR, DFT, and UV-visible spectroscopy. The prepared nanocomposite thin film demonstrated improved photocatalytic efficiency for the degradation of MB dye under $\mathrm{UV}$ and visible light irradiation as compared to pure $\mathrm{ZnO}$ and $\mathrm{N}$-doped $\mathrm{ZnO}$ thin films.

\section{Results and Discussion}

\subsection{XRD Analysis}

The XRD patterns were used to determine the effects of the addition of dopant on the crystal phase, lattice strain, lattice dislocation density, and crystallinity of $\mathrm{ZnO}$ thin films. Figure 1 shows the XRD patterns of (a) pure $\mathrm{ZnO}$, (b) N-doped $\mathrm{ZnO}$, and (c) N-doped $\mathrm{ZnO} / \mathrm{CNT}$ thin films, respectively. All the prepared thin films with high crystallinity revealed a hexagonal wurtzite crystal structure, which mostly matches well with the reported data (JCPDS No. 01-075-0576) [35]. The peaks centered at an angle (20) of 31.91 ${ }^{\circ}$, $34.55^{\circ}, 36.29^{\circ}, 47.75^{\circ}, 56.89^{\circ}, 63.13^{\circ}, 66.47^{\circ}, 68.07^{\circ}$, and $69.33^{\circ}$ corresponding to (100), (002), (101), (102), (110), (103), (200), (112), and (201) planes, respectively. The peaks at $25.7^{\circ}$ and $42.5^{\circ}$ correspond to the (002) and (100) planes of CNT (Figure 1c). The diffraction peaks of the pure $\mathrm{ZnO}$ are sharp and intense, revealing the highly crystalline character of the $\mathrm{ZnO}$ sample, while the diffraction peaks of the $\mathrm{N}$-doped $\mathrm{ZnO}$ and $\mathrm{N}$-doped $\mathrm{ZnO} / \mathrm{CNT}$ are broad and weak (Figure $1 b, c)$, representing a small crystal size of these thin films. The most intense peak $\left(36.29^{\circ}\right)$ of the XRD pattern of bare $\mathrm{ZnO}$ thin films has been little shifted to higher $2 \theta$ values for the $\mathrm{N}$-doped and CNT composite of that materials. This confirms the doping of $\mathrm{ZnO}$ with nitrogen and composite with CNT. In addition, the XRD data were employed to evaluate average size of the crystallites, D from the peak half-width $\beta$, using the Scherrer's equation [21] (Equation (1)):

$$
D=\frac{k \lambda}{\beta \cos \theta}
$$

where $k, \lambda$, and $\theta$ are the shape factor of the particle, wavelength, and the incident angle of the $X$-rays, respectively. According to this Scherrer equation, the average crystallite size for $\mathrm{ZnO}, \mathrm{N}$-doped $\mathrm{ZnO}$, and N-doped $\mathrm{ZnO} / \mathrm{CNTs}$ is $29.07 \mathrm{~nm}, 27.13 \mathrm{~nm}$, and $14.28 \mathrm{~nm}$, respectively. The crystalline sizes have been reduced significantly after addition of dopant nitrogen as well as CNT compared to that of pure ZnO. These results indicate that only doping of nitrogen into $\mathrm{ZnO}$ matrix plays a role to reduce the particle size in $\mathrm{N}$-doped $\mathrm{ZnO}$. Moreover, CNT inhibits the growth of $\mathrm{ZnO}$ crystallites drastically in $\mathrm{N}$-doped $\mathrm{ZnO} / \mathrm{CNT}$ nanocomposite thin film [8].

The lattice strain induced due to the crystal imperfection and distortion in the pure $\mathrm{ZnO}$ thin film, $\mathrm{N}$-doped $\mathrm{ZnO}$, and $\mathrm{N}$-doped $\mathrm{ZnO} / \mathrm{CNT}$ was calculated by the StokesWilson equation (Equation (2)):

$$
E=\beta / 4 \tan \theta
$$

The dislocation density points towards the amount of crystallographic defect or irregularity present in the crystal that strongly influences the properties of the synthesized materials. The dislocation density was calculated by applying the Williamson-Smallman relation [41] (Equation (3)):

$$
\delta=1 / D^{2}
$$




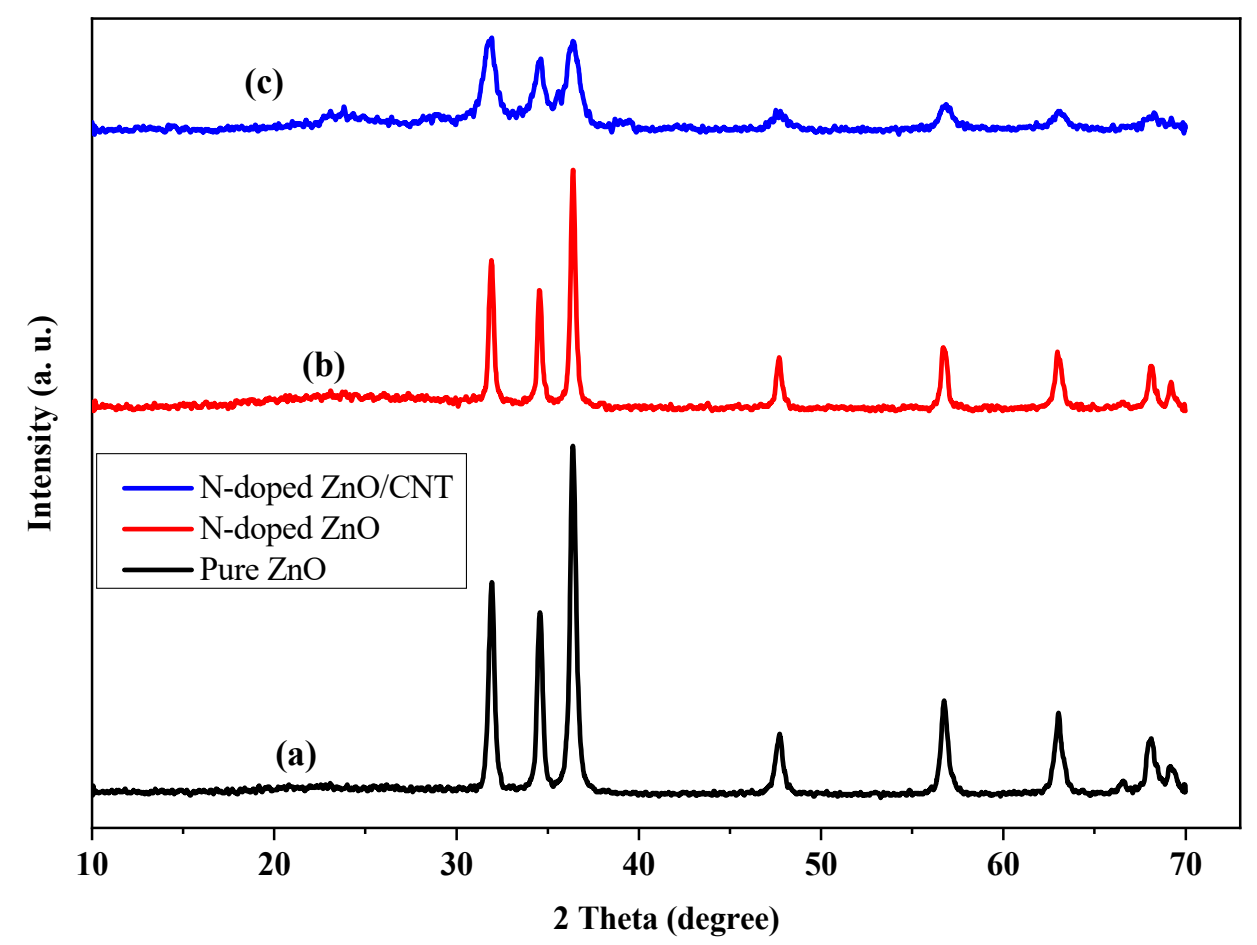

Figure 1. XRD patterns of (a) pure $\mathrm{ZnO}$, (b) N-doped $\mathrm{ZnO}$, and (c) N-doped $\mathrm{ZnO} / \mathrm{CNT}$ thin film.

The average crystallite size, lattice strain, and dislocation density results are summarized in Table 1.

Table 1. Representation of lattice size, lattice strain and dislocation density of pure $\mathrm{ZnO}$, N-doped $\mathrm{ZnO}$ and $\mathrm{N}$-doped $\mathrm{ZnO} / \mathrm{CNT}$ thin film.

\begin{tabular}{cccc}
\hline Sample & $\begin{array}{c}\text { Lattice Size } \\
(\mathbf{D})(\mathbf{n m})\end{array}$ & $\begin{array}{c}\text { Lattice Strain } \\
{\left[(\varepsilon) \times \mathbf{1 0}^{-4}\right]}\end{array}$ & $\begin{array}{c}\text { Dislocation Density }(\boldsymbol{\delta}) \\
\left(\text { lines } / \mathbf{m}^{\mathbf{2}}\right)\end{array}$ \\
\hline Pure ZnO & 29.07 & 30.71 & $1.18 \times 10^{15}$ \\
N-doped ZnO & 27.13 & 33.73 & $1.36 \times 10^{15}$ \\
N-doped ZnO/CNT & 14.28 & 70.64 & $4.90 \times 10^{15}$ \\
\hline
\end{tabular}

The lattice constants a \& $c$ are related to the inter-planar spacing of the atomic planes $\mathrm{d}$ for hexagonal wurzite structure and can be calculated from the XRD spectra by the following equation [41] (Equation (4)):

$$
\frac{1}{d_{h k l}^{2}}=\frac{4}{3}\left(\frac{h^{2}+h k+k^{2}}{a^{2}}\right)+\frac{l^{2}}{c^{2}}
$$

The Miller indices h, k, \& 1 of (100) plane of hexagonal structure is used to calculate the lattice constant $a$ with the help of the following equation [40] (Equation (5)):

$$
a=\frac{\lambda}{\sqrt{ } 3 \sin \theta}
$$

The lattice constant $\mathrm{c}$ is calculated from the reflection (002) plane by using the following equation [42] (Equation (6)):

$$
c=\frac{\lambda}{\sin \theta}
$$


Finally, the unit cell volume of hexagonal pure $\mathrm{ZnO}, \mathrm{N}$-doped $\mathrm{ZnO}$, and $\mathrm{N}$-doped $\mathrm{ZnO} / \mathrm{CNT}$ thin films is calculated by the following equation [43] (Equation (7)):

$$
V=\frac{\sqrt{ } 3}{2} a^{2} c
$$

where $a \& c$ are the lattice constants of the prepared thin films and the obtained results of the lattice constants and the unit cell volume of synthesized thin films are summarized in Table 2. The lattice parameters value is the indication of positive (extensive) or negative (compressive) stress of crystallites if the value is lower or higher than the bulk materials [40]. The value of $c$ is less than the value of bulk $\mathrm{ZnO}$ implies that all the thin films of $\mathrm{ZnO}$ crystallites are the state of compressive stress. The lattice constants $a=b$ and $c$ of hexagonal unit cell exhibit lower value compared with the value of bulk $\mathrm{ZnO}$. It can be seen from Table 2 that the lower unit cell volume of all the prepared thin films compared to the standard is a result of higher stress.

Table 2. Lattice parameters of Pure $\mathrm{ZnO}, \mathrm{N}$-doped $\mathrm{ZnO}$, and $\mathrm{N}$-doped $\mathrm{ZnO} / \mathrm{CNT}$ thin film.

\begin{tabular}{|c|c|c|c|c|c|c|c|}
\hline \multirow[t]{2}{*}{ Sample } & \multicolumn{2}{|c|}{$\begin{array}{l}\text { Lattice Constant } \\
\text { a = b (Ấ) }\end{array}$} & \multicolumn{2}{|c|}{$\begin{array}{c}\text { Lattice Constant } \\
\text { c ( }(\hat{)})\end{array}$} & \multirow{2}{*}{$\begin{array}{c}c / a \\
\text { Ratio }\end{array}$} & \multicolumn{2}{|c|}{$\begin{array}{l}\text { Unit Cell Volume } \\
\text { (V) }\left(\AA^{3}\right)\end{array}$} \\
\hline & Calculated & ASTM & Calculated & ASTM & & Calculated & ASTM \\
\hline Pure $\mathrm{ZnO}$ & 3.2340 & & 5.1842 & & 1.6030 & 46.9579 & \\
\hline $\mathrm{N}-\mathrm{ZnO}$ & 3.2374 & 3.250 & 5.1956 & 5.207 & 1.6048 & 47.1599 & 47.621 \\
\hline $\mathrm{N}-\mathrm{ZnO} / \mathrm{CNT}$ & 3.2467 & & 5.1899 & & 1.5985 & 47.3786 & \\
\hline
\end{tabular}

\subsection{FESEM Analysis}

Figure 2 shows the FESEM images of as synthesized (a) pure $\mathrm{ZnO}$, (b) N-doped $\mathrm{ZnO}$, and $\mathrm{N}$-doped $\mathrm{ZnO} / \mathrm{CNT}$ thin films calcined at $500{ }^{\circ} \mathrm{C}$. The surface morphology of pure $\mathrm{ZnO}$ thin film reveals the irregular spherical shape of particles with some agglomeration while $\mathrm{N}$-doped $\mathrm{ZnO}$ shows a smooth surface with small spherical grains distributed as uniform, compact, and adherent to substrate. However, the morphology of $\mathrm{N}$-doped $\mathrm{ZnO} / \mathrm{CNT}$ is formed in a more consistent spherical shape with a lower degree of agglomeration. The comparatively homogeneous morphology (Figure 2c) might be due to the inclusion of functionalized CNT that contains the polar functional groups on its surface that impede the agglomeration of nanoparticles. However, it looks very difficult to figure out the CNT structure from Figure $3 \mathrm{c}$ with that low resolution image. In addition, the uniform and small size of the catalyst particle can contribute to a greater adsorption of dye on surface and more light absorption in this photocatalytic system. With the inclusion of dopant nitrogen and CNT, the grain size decreases from 30 to $14 \mathrm{~nm}$. The unevenness and grain size decrease because of the doping nitrogen as well as CNT that ascribe the enhancement in crystalline quality. 


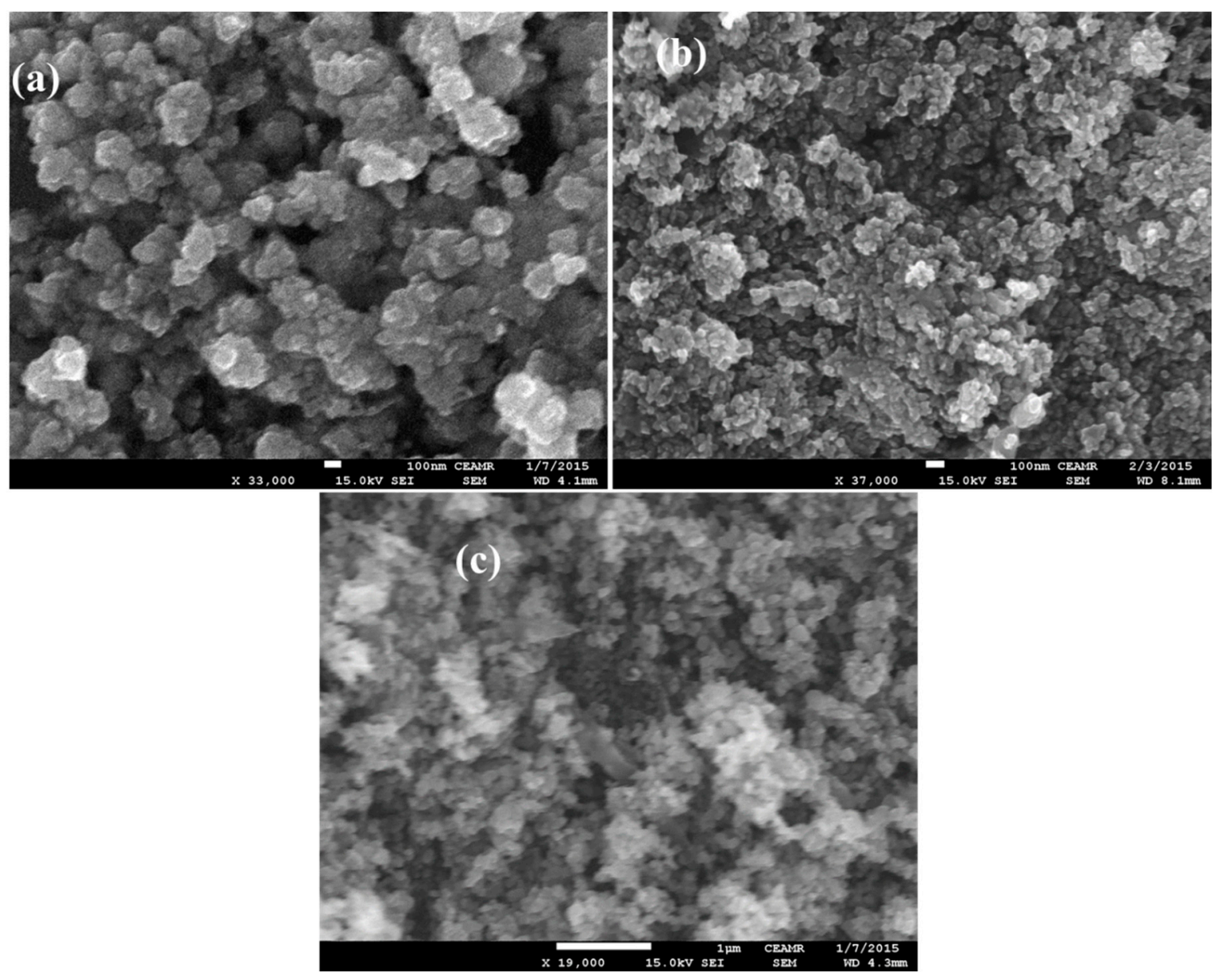

Figure 2. FESEM images of (a) pure $\mathrm{ZnO}$; (b) N-doped $\mathrm{ZnO}$; and (c) N-doped ZnO/CNT nanocomposite thin films.

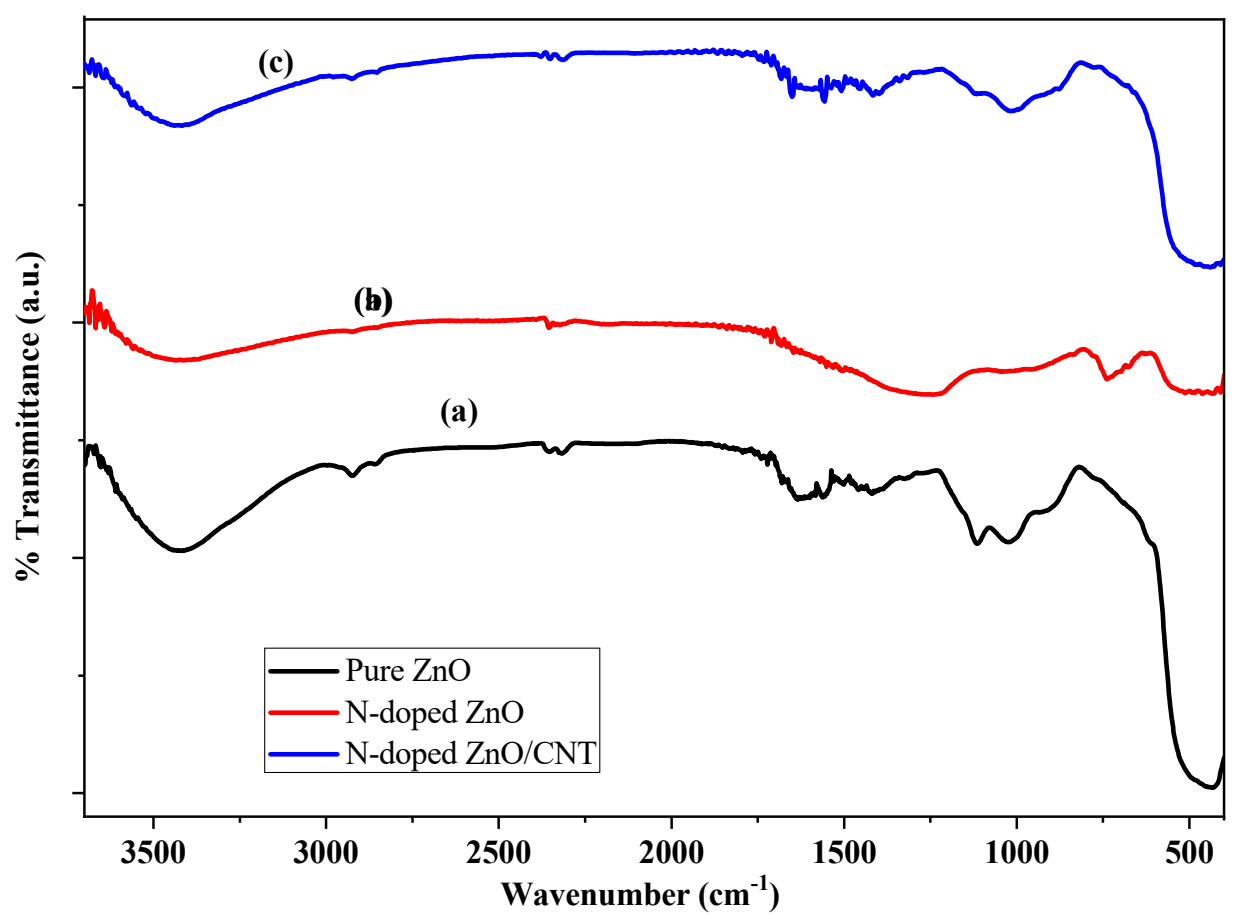

Figure 3. FT-IR spectra of (a) pure ZnO; (b) N-doped ZnO; and (c) N-doped ZnO/CNT nanocomposite thin films. 


\subsection{FT-IR Analysis}

The FT-IR spectrum illustrates the information of a particular compound about its functional groups, molecular geometry, and inter/intramolecular interactions. Figure 3 displays the FT-IR spectra of as prepared (a) pure $\mathrm{ZnO}$, (b) N-doped $\mathrm{ZnO}$, and (c) N-doped $\mathrm{ZnO} / \mathrm{CNT}$ nanocomposite thin film, respectively, and those were performed in the wave number range $400-4000 \mathrm{~cm}^{-1}$ using the $\mathrm{KBr}$ method at room temperature. All FT-IR spectra display a broad absorption band at around $3400-3600 \mathrm{~cm}^{-1}$ due to the presence of the O-H stretching mode of the hydroxyl groups. The absorption band around $2800-2900 \mathrm{~cm}^{-1}$ is identified as a stretching mode for the $\mathrm{C}-\mathrm{H}$ bond of binder TEA. The band at $1650 \mathrm{~cm}^{-1}$ characterizes the $\mathrm{H}-\mathrm{O}-\mathrm{H}$ bending vibration of water. The bands in the low wave number region, $426 \mathrm{~cm}^{-1}$, correspond to the vibration modes of $\mathrm{Zn}-\mathrm{O}$ [41]. It is assumed that the bands appearing at $1109 \mathrm{~cm}^{-1}$ and $1020 \mathrm{~cm}^{-1}$ are due to stretching vibrations of $\mathrm{Zn}-\mathrm{O}-\mathrm{Si}$ and Si-O-Si that appear from the glass substrate [44].

\subsection{UV-Visible Absorption Spectra Analysis}

The photocatalytic activity of photocatalyst depends on the light absorption capacity. UV-visible absorption spectra have been measured to determine the optical properties of the prepared thin films and the obtained results are shown in Figure 4a. The pure $\mathrm{ZnO}$ has an absorption maximum at $362 \mathrm{~nm}$, whereas the peaks at $368 \mathrm{~nm}$ and $366 \mathrm{~nm}$ are obtained for the $\mathrm{N}$-doped $\mathrm{ZnO} / \mathrm{CNT}$ and $\mathrm{N}$-doped $\mathrm{ZnO}$, respectively. The presence of absorption peak indicates the electronic transition from valence band to conduction band of $\mathrm{ZnO}$ nanoparticles [45]. It can be seen that $\mathrm{N}$-doping has an influence on the absorption spectrum into UV to the visible region (red shift). The similar results are also found in the references for the redshift in the absorption edge [30]. The band gap of prepared thin films has been calculated with help of the following Tauc equation (Equation (8)):

$$
\alpha \mathrm{h} v=(\mathrm{h} v-\mathrm{Eg}) 1 / 2
$$

where Eg is the band gap energy, $\mathrm{h} v$ is the photon energy, and $\alpha$ refers to the absorption coefficient, by plotting the value $\alpha \mathrm{h} v$ along the $y$-axis and $\mathrm{h} v$ along the $x$-axis followed by the extrapolating the liner portion of the curve to $h v$ axis $(\alpha h v)^{2}=0$ (Figure $4 b$ ). The estimated band gap of pure $\mathrm{ZnO}, \mathrm{N}$-doped $\mathrm{ZnO}$ and $\mathrm{N}$-doped $\mathrm{ZnO} / \mathrm{CNT}$ is $3.18 \mathrm{eV}, 2.90 \mathrm{eV}$ and $2.65 \mathrm{eV}$, respectively.
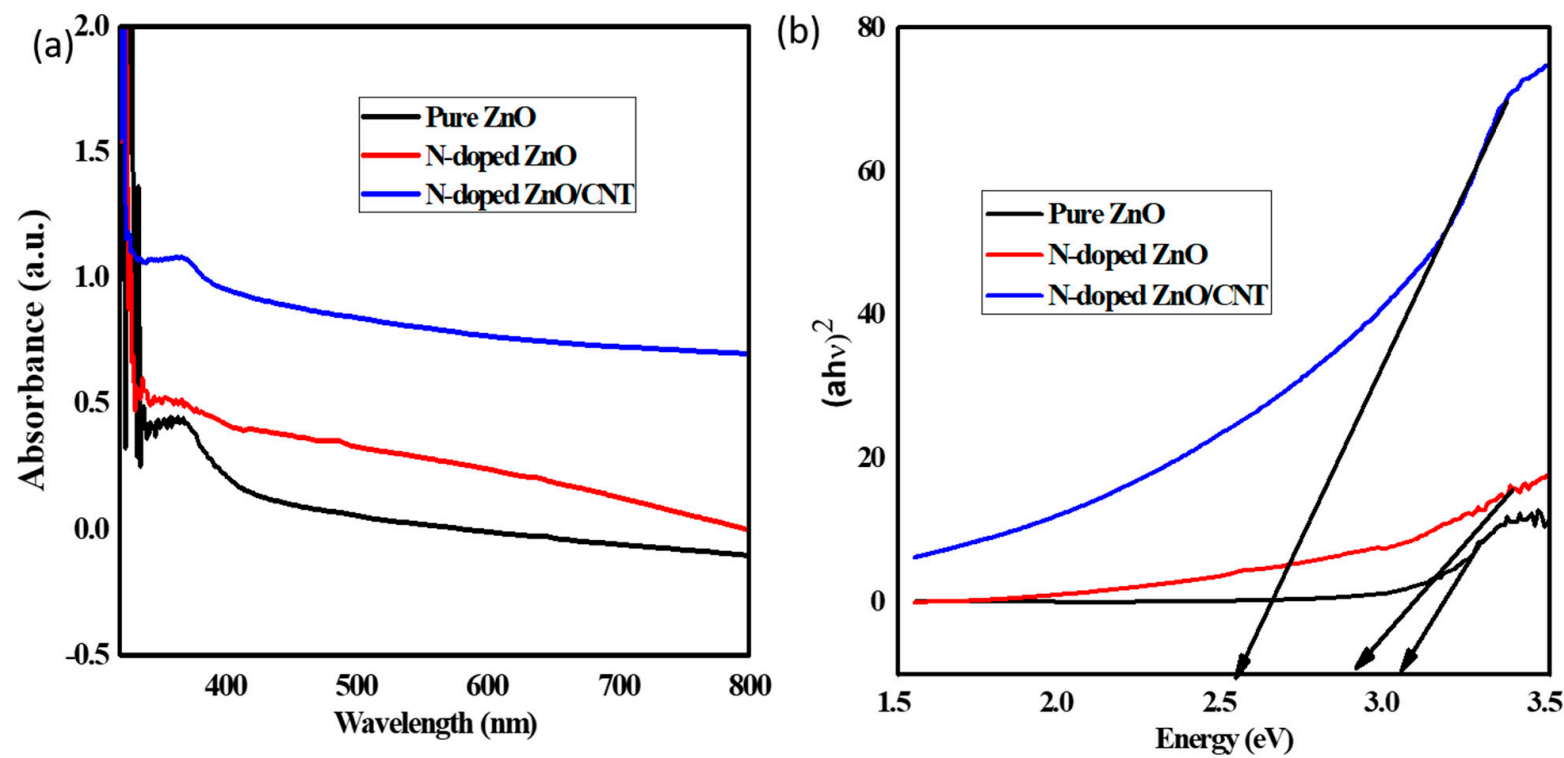

Figure 4. (a) UV-vis absorption spectra of pure $\mathrm{ZnO}$, N-doped $\mathrm{ZnO}$ and $\mathrm{N}$-doped $\mathrm{ZnO} / \mathrm{CNT}$ thin films; (b) calculated band gap from Tauc plot of pure $\mathrm{ZnO}, \mathrm{N}$-doped $\mathrm{ZnO}$ and $\mathrm{N}$-doped $\mathrm{ZnO} / \mathrm{CNT}$ thin film photocatalysts. 


\subsection{Density Functional Theory (DFT) Study}

The lattice parameters of optimized $\mathrm{Zn}_{8} \mathrm{O}_{8} \mathrm{a}=\mathrm{b}=3.127 \AA$ and $\mathrm{c}=5.032 \AA$ are in good agreement with experimental values (Table 2 ). After nitrogen doping, the lattice parameters of $\mathrm{N}$-doped $\mathrm{Zn}_{8} \mathrm{O}_{8}(\mathrm{a}=\mathrm{b}=3.124 \AA$ and $\mathrm{c}=5.098 \AA)$ changes $0.003 \AA$ and $0.066 \AA$ for $\mathrm{a}$ and c, respectively. Theoretically calculated lattice parameters deviate $3.3 \%$ from those that are experimentally measured. To determine the effect of nitrogen doping in $\mathrm{ZnO}$, band structure and total density of states (TDOS) of $\mathrm{ZnO}$ and $\mathrm{N}$-doped $\mathrm{ZnO}$ have been calculated as shown in Figure 5. The band structure shows the band gap of $\mathrm{ZnO}$ is $2.18 \mathrm{eV}$, which is lower than that experimentally obtained. This deviation is originated because the DFT calculation is concerned with only the ground state [46]. After nitrogen doping, the band gap reduces to $1.71 \mathrm{eV}$, which is relevant for UV-visible absorption spectrum. To justify this, we calculated the total density of states (TDOS). The peak of the valence band maximum (VBM) of $\mathrm{ZnO}$ is located below the Fermi level. However, nitrogen doping in $\mathrm{ZnO}$ attributes the upward shift of VBM to reduce the band gap. There is almost no effect of nitrogen doping on conduction band minimum (CBM) of $\mathrm{ZnO}$.
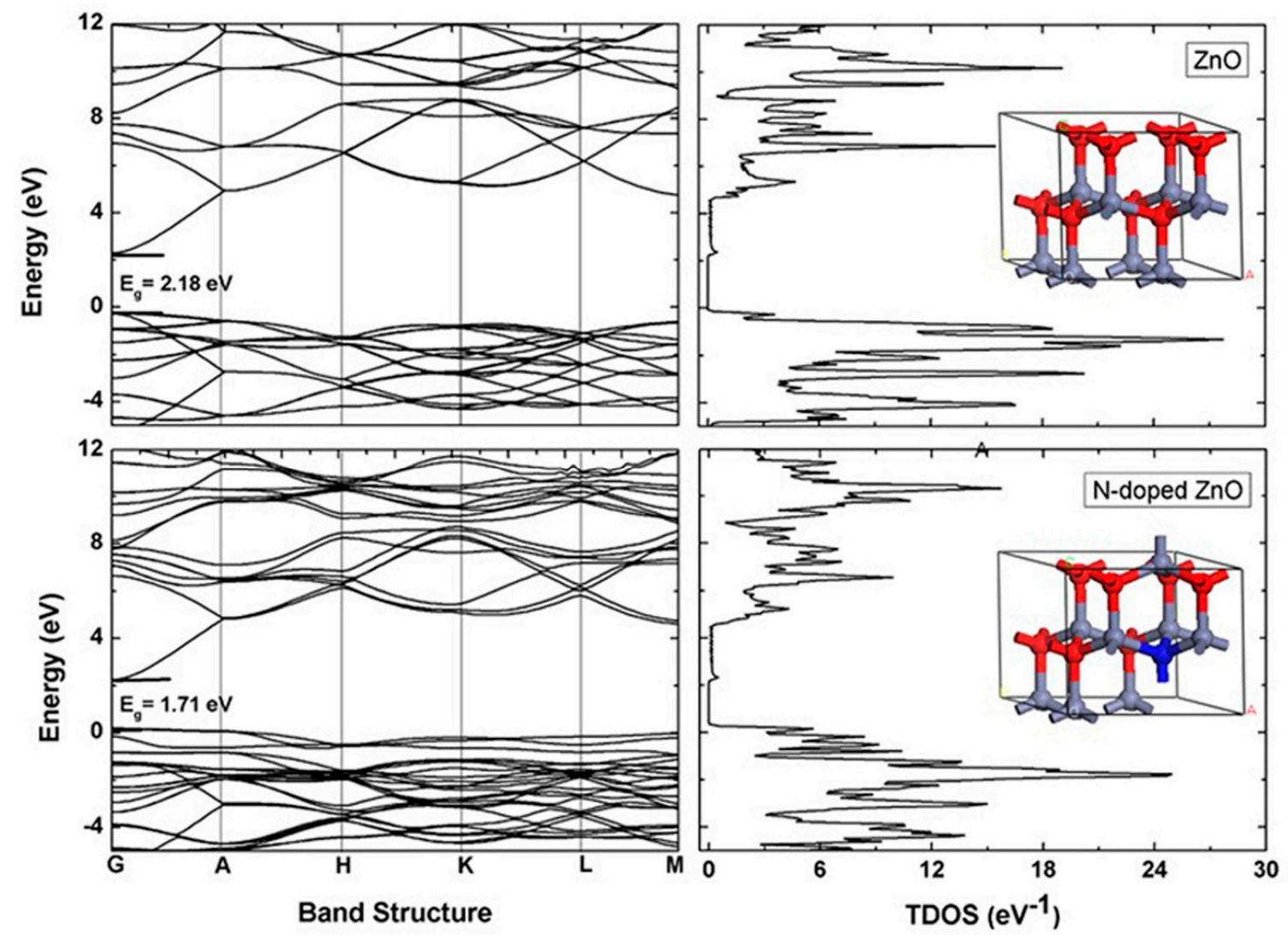

Figure 5. Calculated electronic band structure and total density of states of $\mathrm{ZnO}$ (top) and N-doped $\mathrm{ZnO}$ (bottom) using the DFT-GGA+U method. The inset figure shows the optimized structure of ZnO (top) and N-doped ZnO (bottom) with periodic boundary condition. Red, blue yonder, and blue represent oxygen, zinc and nitrogen atom, respectively.

\subsection{Photocatalytic Activity Evaluation}

The photocatalytic performance of pure $\mathrm{ZnO}, \mathrm{N}$-doped $\mathrm{ZnO}$, and $\mathrm{N}$-doped $\mathrm{ZnO} / \mathrm{CNT}$ thin films in degradation of $\mathrm{MB}$ dye was carried out under $\mathrm{UV}$ and visible light irradiation and results are shown in Figure 6. To confirm the photolysis and adsorption onto thin film, the adsorption as well as photodegradation experiments were conducted separately under visible light and UV light irradiation for $4 \mathrm{~h}$. For both studies, no appreciable changes were observed due to adsorption and self photodegradation of the MB dye. About $100 \%$ of MB is degraded by an $\mathrm{N}$-doped $\mathrm{ZnO} / \mathrm{CNT}$ nanocomposite thin film photocatalyst within $4 \mathrm{~h}$ 
under UV light irradiation, while the efficiency is $63.69 \%$ under visible light irradiation. From Figure 6, it was noticed that about $60 \%$ of MB was removed after 60 min by UV light irradiation for N-doped $\mathrm{ZnO} / \mathrm{CNT}$, whereas only $16.66 \%$ and $28.57 \%$ for pure $\mathrm{ZnO}$ and Ndoped $\mathrm{ZnO}$ photocatalysts. In case of visible light irradiation, the effectiveness of pure $\mathrm{ZnO}$ has $23.41 \%$ degradation efficiency, much less compared with $\mathrm{N}$-doped $\mathrm{ZnO}(34.62 \%)$ and $\mathrm{N}$ doped $\mathrm{ZnO} / \mathrm{CNT}(63.69 \%)$. These results clarify that $\mathrm{N}$ doping enhances the photocatalytic efficiency of plain $\mathrm{ZnO}$ by reducing the band gap. On the other hand, CNTs improved the interfacial electron transfer rate and lessened the recombination possibility between photo-induced electron hole pair $\left(\mathrm{e}^{-} / \mathrm{h}^{+}\right)$more effectively than the $\mathrm{ZnO}$ photocatalyst alone. It could be summarized that the reduction of $\mathrm{e}^{-} / \mathrm{h}^{+}$recombination and generation of more ${ }^{\bullet} \mathrm{OH}$ radicals in the $\mathrm{N}$ doped $\mathrm{ZnO}$ as well as $\mathrm{N}$-doped $\mathrm{ZnO} / \mathrm{CNT}$ samples play a vital role in the improved rate of photocatalytic degradation. The produced $\bullet \mathrm{OH}$ radicals have strong enough reactivity to break different $(C-C, C=C$, and $C=O)$ bonds in $M B$ molecules lead to the formation of $\mathrm{CO}_{2}$ and $\mathrm{H}_{2} \mathrm{O}$ at the end. However, many researchers have used numerous pollutants such as 4-cholorophenol, antibiotics, and natural organic matters, in order to examine the feasibility of the photocatalyst $[2,47,48]$.
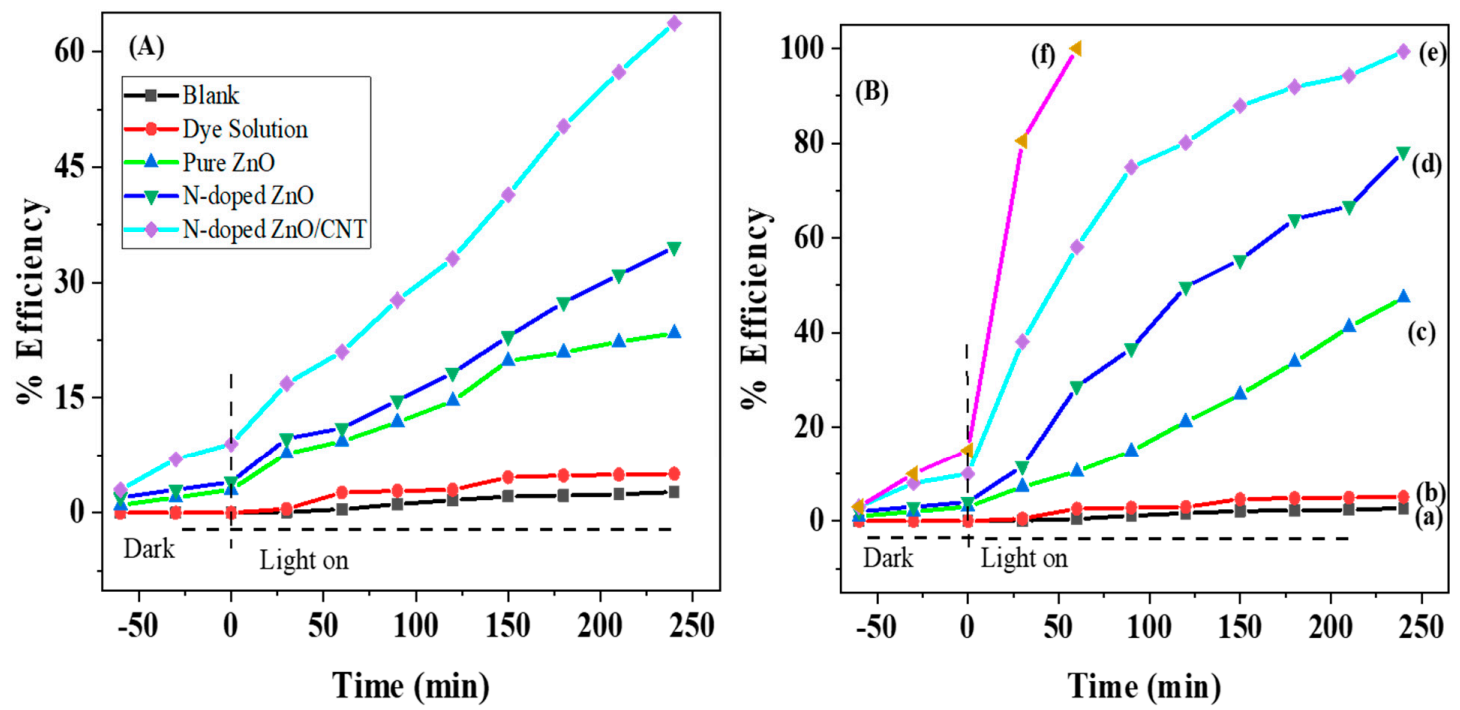

Figure 6. (A) Photo-catalytic degradation efficiencies of methylene blue under Visible light irradiation, (B) under UV light irradiation: (a) blank; (b) dye solution; (c) pure ZnO; (d) N-doped ZnO; (e) N-doped ZnO/CNT; and (f) N-doped ZnO/CNT $+\mathrm{H}_{2} \mathrm{O}_{2}$, respectively.

Recent reports point out that several oxidants such as peroxymonosulfate, hydrogen peroxide $\left(\mathrm{H}_{2} \mathrm{O}_{2}\right)$, peroxydisulfate, $\mathrm{ClO}_{3}{ }^{-}$etc. in heterogeneous photocatalytic system increase the degradation efficiency either by lowering $\mathrm{e}^{-} / \mathrm{h}^{+}$recombination rate through accepting the conduction band electrons at the surface of $\mathrm{ZnO}$ photocatalyst or by providing additional oxygen atoms as an electron acceptor to form the superoxide radical ion $\left(\mathrm{O}_{2}{ }^{\bullet-}\right)$ [48]. Herein, the effect of varying dose of oxidant $\mathrm{H}_{2} \mathrm{O}_{2}(5-30 \mathrm{mmol})$ was studied in case of $\mathrm{N}$-doped $\mathrm{ZnO} / \mathrm{CNT}$ nanocomposite photocatalyst thin film for MB dye degradation under UV light irradiation. The results showed that $\mathrm{MB}$ dye degradation increases due to the addition of $\mathrm{H}_{2} \mathrm{O}_{2}$ and the $\mathrm{MB}$ dye degradation efficiency was $100 \%$ within 60 min under UV light irradiation for $5 \mathrm{mmol} \mathrm{H}_{2} \mathrm{O}_{2}$. The results of degradation efficiency were similar up to $25 \mathrm{mmol} \mathrm{H}_{2} \mathrm{O}_{2}$, whereas, for additional doses like above $25 \mathrm{mmol}$ of $\mathrm{H}_{2} \mathrm{O}_{2}$, the degradation efficiency was not changed. The higher degree of degradation is due to the formation of highly reactive radical intermediates and the electron capture by oxidant $\mathrm{H}_{2} \mathrm{O}_{2}$. As a consequence, the addition of $\mathrm{H}_{2} \mathrm{O}_{2}$ to the heterogeneous system increases the concentration of $\bullet \mathrm{OH}$ radicals.

$\mathrm{N}$-doped $\mathrm{ZnO} / \mathrm{CNT}$ (electron from conduction band) $+\mathrm{H}_{2} \mathrm{O}_{2} \rightarrow \mathrm{N}$-dopedZnO/CNT $+\mathrm{OH}^{-}+\mathrm{OH}^{\bullet}$ 
As $\mathrm{H}_{2} \mathrm{O}_{2}$ is an electron acceptor species, it does not only produce ${ }^{\bullet} \mathrm{OH}$ radicals but also obstructs the electron hole recombination [48]. When the $\mathrm{H}_{2} \mathrm{O}_{2}$ concentration becomes high, the excess $\mathrm{H}_{2} \mathrm{O}_{2}$ consumes hydroxyl radicals as scavenger [49] (Equation (9)):

$$
\mathrm{H}_{2} \mathrm{O}_{2}+\bullet{ }^{\bullet} \mathrm{OH} \rightarrow \mathrm{HO}_{2}^{\bullet}+\mathrm{H}_{2} \mathrm{O}
$$

When $\mathrm{H}_{2} \mathrm{O}_{2}$ was added, the maximum degradation was achieved in the first $60 \mathrm{~min}$ only, whereas, without oxidants, it took $240 \mathrm{~min}$ for the $100 \%$ degradation. The influence of initial dye concentration on photocatalytic degradation is defined by the LangmuirHinshelwood kinetic model (Equation (10)) [50]:

$$
\mathrm{r}=-\frac{[M B]}{d t}=-\frac{k K[M B]}{1+K[M B]}
$$

where $\mathrm{r}$ is the rate of reaction, $k$ is the reaction rate constant $\left(\mathrm{mgL}^{-1} \mathrm{~min}^{-1}\right), K$ is the observed equilibrium constant of the reactant $\left(\mathrm{Lmg}^{-1}\right)$, and $[M B]$ is the reactant concentration $\left(\mathrm{mg} \mathrm{L}^{-1}\right)$. When $[M B]$ is very small, $K[M B]$ is negligible with respect to unity and photocatalysis can be simplified to an apparent pseudo-first-order kinetics [51]. Therefore,

$$
\mathrm{r}=-\frac{[M B]}{d t}=k K[M B]
$$

Integration of Equation (11) gives

$$
\ln \left(\frac{[M B]_{0}}{[M B]}\right)=k_{o b s} t
$$

where $k_{\text {obs }}$ is the observed pseudo-first-order rate constant $\left(\mathrm{min}^{-1}\right)$. A plot of $\ln \left(\frac{[M B]_{0}}{[M B]}\right)$ vs. irradiation time $t$ provided a straight line with their rate constants at different initial concentrations of $M B$ (Figure 7). The observed degradation rate and correlation coefficients are represented in Table 3. All correlation coefficients values suggest that the proposed kinetic model was in excellent agreement with our experimental data. N-doped ZnO/CNT under UV light irradiation shows the best photocatalytic performance with a rate constant much higher than those of $\mathrm{N}$-doped $\mathrm{ZnO}$ and bare $\mathrm{ZnO}$ under visible as well as UV light irradiation. The same result was observed by Hadi et al. during the photo-catalytic degradation of MB dyes using Tungsten doped zinc oxide as photocatalysts [52].

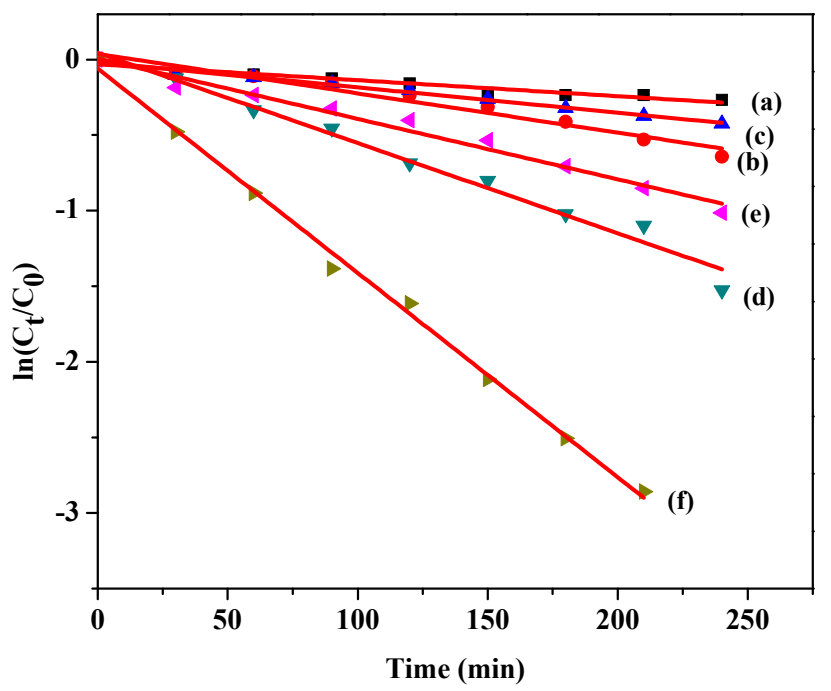

Figure 7. First order kinetics of $\mathrm{MB}$ dye degradation by Pure $\mathrm{ZnO}$ (a) visible light \& (b) UV light; $\mathrm{N}$-doped ZnO (c) visible light \& (d) UV light; and N-doped ZnO/CNT (e) visible light \& (f) UV light irradiation, respectively. 
Table 3. Values of rate constant $(\mathrm{k})$ and correlation coefficient $\left(\mathrm{r}^{2}\right)$ for $\mathrm{MB}$ dye degradation kinetics.

\begin{tabular}{ccc}
\hline Thin Film Photocatalyst & Rate Constant, $\mathbf{k}\left(\mathbf{m i n}^{-\mathbf{1}}\right)$ & Correlation Coefficients $\left.\mathbf{( r}^{\mathbf{2}}\right)$ \\
\hline (a) Bare ZnO under vis & 0.0010 & 0.94376 \\
(b) Bare ZnO under UV & 0.0026 & 0.96763 \\
(c) N-doped ZnO under vis & 0.0017 & 0.98564 \\
(d) N-doped ZnO under UV & 0.0060 & 0.97787 \\
(e) N-doped ZnO/CNT under vis & 0.0040 & 0.96608 \\
(f) N-doped ZnO/CNT under UV & 0.0135 & 0.99619 \\
\hline
\end{tabular}

\subsection{Study of Photocatalyst Stability and Reusability}

The long-term stability and recyclability of photocatalyst thin film are very crucial for MB dye degradation as well as large scale practical utilization in the industry. Therefore, the reusability of a prepared $\mathrm{N}$-doped $\mathrm{ZnO} / \mathrm{CNT}$ nanocomposite thin film was examined by five consecutive cycles for the degradation of MB dye under UV light illumination, and results are shown in Figure 8. After every test, the thin film composite photocatalyst was washed with distilled water and dried naturally at room temperature followed by the heat treatment at $500{ }^{\circ} \mathrm{C}$ for $1 \mathrm{~h}$. After that, a thin film was applied for a second cycle MB dye degradation test like the first cycle experiment. The degradation efficiency of MB dye was reduced to about $5 \%$ after five successive cycles, which means that degradation efficiency reached $95 \%$ from $100 \%$ after five recycling times. These results definitely indicate that the fabricated $\mathrm{N}$-doped $\mathrm{ZnO} / \mathrm{CNT}$ nanocomposite thin film photocatalyst is highly stable and reusable. Furthermore, a comparison of the photocatalytic activity of the N-doped $\mathrm{ZnO} / \mathrm{CNT}$ thin film photocatalyst with previously reported photocatalysts was listed in Table 4 . From the Table 4, it is clear that degradation efficiency and reusability of N-doped $\mathrm{ZnO} / \mathrm{CNT}$ nanocomposites are comparable to the results with earlier reported $\mathrm{ZnO}$-based materials.

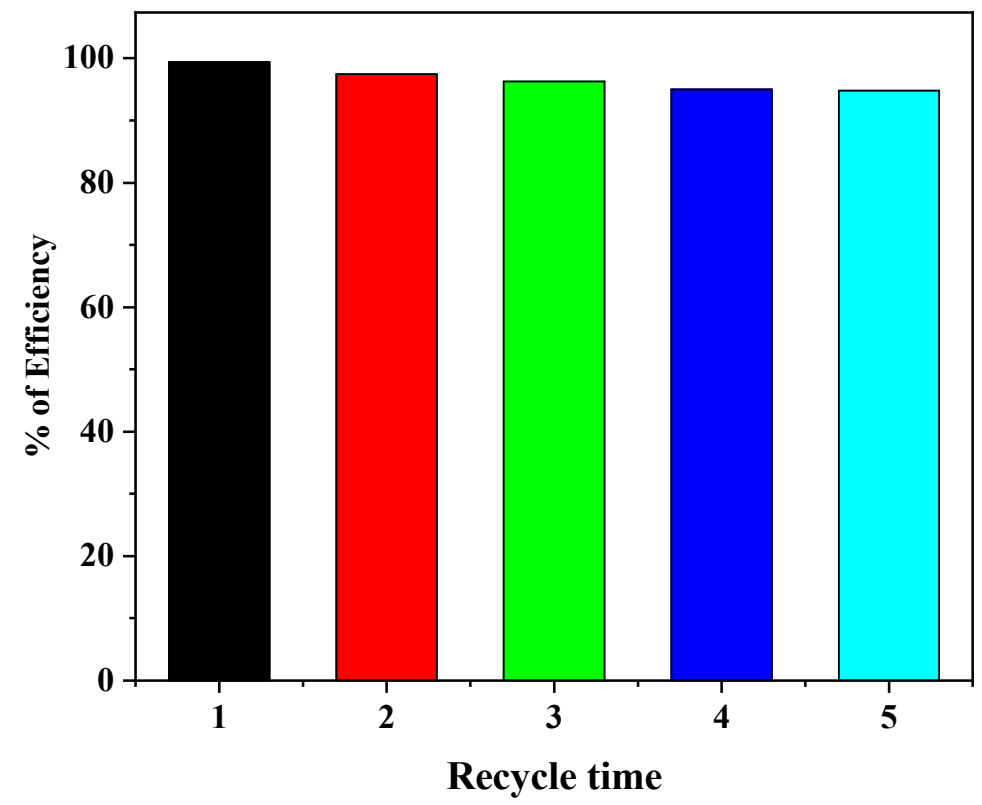

Figure 8. Recycle and reuse of photocatalyst for $\mathrm{MB}$ degradation under UV light irradiation (MB concentration: 5 ppm; photocatalyst: N-doped ZnO/CNT; solution pH 6.4; irradiation time: $4 \mathrm{~h}$ ). 
Table 4. Comparison of degradation percentage of N-doped ZnO/CNT composite photocatalysts with previously reported composite photocatalysts.

\begin{tabular}{|c|c|c|c|c|c|c|c|c|}
\hline $\begin{array}{c}\text { Type of } \\
\text { Photocatalyst }\end{array}$ & $\begin{array}{l}\text { Model } \\
\text { Pollutant }\end{array}$ & Conc. & $\begin{array}{l}\text { Light } \\
\text { Source }\end{array}$ & $\begin{array}{l}\text { Illumination } \\
\text { Time min }\end{array}$ & $\begin{array}{l}\text { a DE } \\
\text { in } \%\end{array}$ & $\begin{array}{c}\text { Ref. } \\
\text { Photocatalyst; }^{\text {a }} \\
\text { DE in } \%\end{array}$ & Reusability & Ref. \\
\hline $\mathrm{ZnO}-\mathrm{rGO}$ & MB & $5 \mathrm{mg}$ & $500 \mathrm{~W} X \mathrm{X}$ & 260 & 88 & Pure $\mathrm{ZnO} ; 68$ & - & [17] \\
\hline $\mathrm{ZnO}-\mathrm{CNT}$ & $\mathrm{MO}$ & $10 \mathrm{mg}$ & $60 \mathrm{~W} \mathrm{Hg}$ & 260 & 98 & Pure $\mathrm{ZnO}, 35$ & 4 cycles & [53] \\
\hline $\mathrm{g}-\mathrm{C}_{3} \mathrm{~N}_{4} / \mathrm{ZnO}$ & RhB & $0.05 \mathrm{~g}$ & $500 \mathrm{~W} X \mathrm{e}$ & 100 & 97.4 & Pure $\mathrm{ZnO} ; 48$ & 5 cycles & [54] \\
\hline $\mathrm{Mg}-\mathrm{ZnO} / \mathrm{CNT}$ & MB & $10 \mathrm{mg}$ & $150 \mathrm{~W}$ Xe & 60 & 84 & Pure $\mathrm{ZnO} ; 20$ & 5 cycles & [55] \\
\hline $\mathrm{Cd}-\mathrm{ZnO} / \mathrm{CNT}$ & $\mathrm{MO}$ & $20 \mathrm{mg}$ & $15 \mathrm{~W} \mathrm{Hg}$ & 110 & 93 & $\mathrm{ZnO} / \mathrm{CNT} ; 44$ & - & [39] \\
\hline $\mathrm{N}-\mathrm{ZnO} / \mathrm{C}$-dots & MG & $20 \mathrm{mg}$ & $150 \mathrm{~W}$ Vis & 160 & 85 & Pure $\mathrm{ZnO} ; 65$ & - & [56] \\
\hline $\mathrm{N}-\mathrm{ZnO} / \mathrm{CNT}$ & MB & $5 \mathrm{mg}$ & $60 \mathrm{~W} \mathrm{Hg}$ & 240 & 100 & Pure $\mathrm{ZnO}, 47.36$ & 5 cycles & This work \\
\hline $\mathrm{N}-\mathrm{ZnO} / \mathrm{CNT}$ & MB & $5 \mathrm{mg}$ & $\begin{array}{c}200 \mathrm{~W} \\
\text { Tungsten }\end{array}$ & 240 & 70 & Pure $\mathrm{ZnO}, 25$ & & This work \\
\hline
\end{tabular}

\subsection{Photocatalytic Degradation Mechanism}

The excellent photocatalytic efficiency of synthesized N-doped ZnO/CNT composite supports the following degradation mechanism of MB dye under UV light irradiation as described by Chemical equations (1-7). The computational and theoretical studies confirm the incorporation of dopant $\mathrm{N}$ into the $\mathrm{ZnO}$ matrix and doesn't change the wurzite structure of $\mathrm{ZnO}$; it only replaces the $\mathrm{O}$ atom with an $\mathrm{N}$ atom. Upon illumination of $\mathrm{N}$ doped $\mathrm{ZnO} / \mathrm{CNT}$ composite semiconductor photocatalysts by the UV light having energy $\left(h v>>E_{g}\right.$ ) greater than the band gap results in the formation of charge carriers' electronholes $\left(\mathrm{e}^{-} / \mathrm{h}^{+}\right)$. These electron-holes $\left(\mathrm{e}^{-} / \mathrm{h}^{+}\right)$recombine quickly, thereby producing minute amounts of highly reactive oxidizing species such as hydroxyl radicals, hydrogen peroxide, and superoxides that take part in the photocatalytic degradation of MB dye. However, the addition of $\mathrm{CNT}$ with the $\mathrm{N}$-doped $\mathrm{ZnO}$ forms a heterojunction interface that can reduce the electron-hole recombination rate:

(1) N-doped $\mathrm{ZnO} / \mathrm{CNT}$ composite $+h v \rightarrow \mathrm{h}_{\mathrm{vb}}{ }^{+}+\mathrm{e}_{\mathrm{cb}}{ }^{-}(\mathrm{CNT})$

(2) $\mathrm{H}_{2} \mathrm{O}+\mathrm{h}^{+} \rightarrow \mathrm{H}^{+}+\mathrm{OH}^{\bullet}$

(3) $\mathrm{OH}^{-}+\mathrm{h}^{+} \rightarrow \mathrm{OH}^{\bullet}$

(4) $\mathrm{O}_{2}+\mathrm{e}^{-}(\mathrm{CNT}) \rightarrow \mathrm{O}_{2}^{\bullet}$

(5) $\mathrm{O}_{2}{ }^{-}+\mathrm{H}_{2} \mathrm{O}+\mathrm{H}^{+} \rightarrow \mathrm{H}_{2} \mathrm{O}_{2}+\mathrm{OH}^{-}$

(6) $\mathrm{H}_{2} \mathrm{O}_{2}+\mathrm{e}^{-} \rightarrow \mathrm{OH}^{\bullet}+\mathrm{OH}^{-}$

(7) $\mathrm{OH}^{\bullet}+\mathrm{MB} \rightarrow \mathrm{H}_{2} \mathrm{O}+\mathrm{CO}_{2}$

The improved degradation efficiency of $\mathrm{N}$-doped $\mathrm{ZnO} / \mathrm{CNT}$ composite is due to the synergistic effect of CNT into N-doped $\mathrm{ZnO}$ as shown in Figure 9.

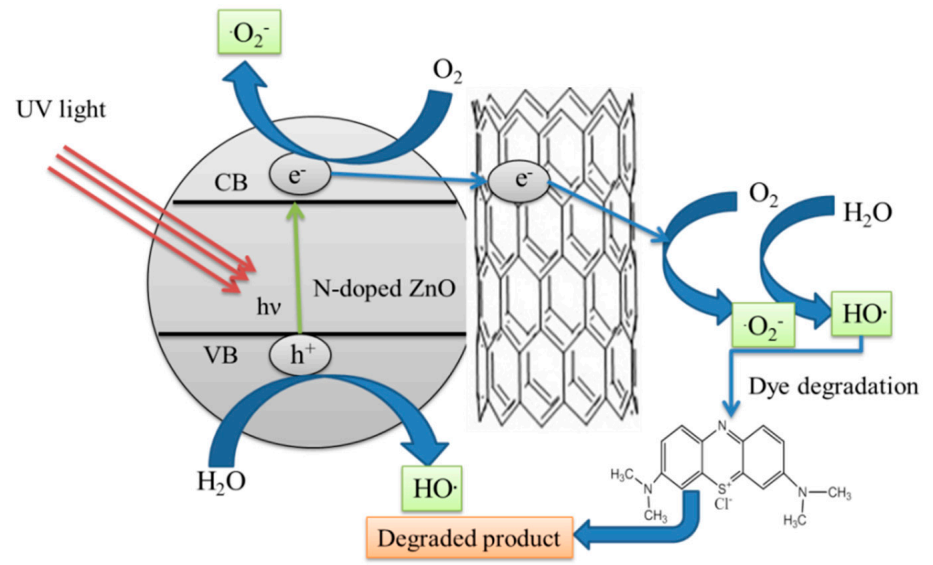

Figure 9. Schematic illustration of photocatalytic mechanism of the N-doped ZnO/CNT thin films under UV light irradiation. 


\section{Experimental Section}

\subsection{Materials}

Multi-walled carbon nanotubes (MWCNT) were collected from Sigma-Aldrich (St. Loius, MO, USA) with the particulars as follows: length $(5-9 \mu \mathrm{m})$, diameter $(110-170 \mathrm{~nm})$ and assay $>90 \%$ (carbon basis). Zinc acetate dihydrate $\left(\mathrm{Zn}\left(\mathrm{CH}_{3} \mathrm{COO}\right)_{2} \cdot 2 \mathrm{H}_{2} \mathrm{O}\right.$; Merck, Darmstadt, Germany), tri-ethylamine (TEA) ( $\geq 99 \%$, Sigma Aldrich, St. Loius, MO, USA) were purchased to use as $\mathrm{Zn}$ provider and stabilizing agent, respectively. Urea, hydrogen peroxide, sulfuric acid, nitric acid, and methylene blue (MB) dye were acquired from Sigma Aldrich (St. Loius, MO, USA). All other reagents were analytical grade and used as received.

\subsection{Functionalization of $C N T$}

Functionalization of CNT leads to the oxygenated polar functional groups on its surface. Therefore, oxygenated polar functionalities enhance the binding of CNT with ZnO through some physical/chemical interactions, for instance hydrogen bonding, van der Waals attraction as well as other bonds. In addition, the acid treatments (functionalization) also reduce the impurities of the amorphous carbon as well as unfold the ends and or break the tubes. In a typical functionalization, fresh MWCNT $(1 \mathrm{~g})$ was immersed into $40 \mathrm{~mL}$ of mixed solution (1:1 ratio) of concentrated sulfuric acid and nitric acid. [35]. Then, the combined solution was refluxed for $5 \mathrm{~h}$ at $60-70{ }^{\circ} \mathrm{C}$ in an oil bath to get dark-brown suspension. After completion of reaction, the prepared suspension was separated by centrifugation after cooling at room temperature. Thereafter, the product was washed with de-ionized water and ethanol until the $\mathrm{pH}$ of the filtrate become neutral, and dried in vacuum oven at $80^{\circ} \mathrm{C}$ to use in the next step.

\subsection{Fabrication of $\mathrm{N}$-Doped $\mathrm{ZnO} / \mathrm{CNT}$ Thin Film}

$\mathrm{N}$-doped $\mathrm{ZnO} / \mathrm{CNT}$ thin film was fabricated by applying sol-gel drop coating protocol according to the literature with some modifications [57]. Typically, to prepare the $\mathrm{N}$-doped $\mathrm{ZnO} / \mathrm{CNT}, 0.7316 \mathrm{~g}$ of zinc acetate dihydrate and $0.4 \mathrm{~mL}$ of tri-ethylamine were first dissolved in $9.6 \mathrm{~mL}$ of anhydrous ethanol under stirring environment ( $300 \mathrm{rpm}$ ) for 4-5 min, followed by the addition of $5 \mathrm{wt} \%$ of nitrogen (urea) $(28 \mathrm{mg}$ urea) and $5 \mathrm{wt} \%$ of CNTs $(5 \mathrm{mg}$ ) to the above solution. The resultant solution was sonicated (Powersonic 405, Hwashin Technology Co., Seoul, Korea) for $1 \mathrm{~h}$ to obtain a uniform dispersion. Then, the solution was preserved for $1 \mathrm{~h}$ maintaining temperature $(55 \pm 5)^{\circ} \mathrm{C}$ with continuous stirring at $300 \mathrm{rpm}$ until a quite stable and transparent sol was obtained. Prior to the coating process, the stable $\mathrm{N}$-doped $\mathrm{ZnO} / \mathrm{CNT}$ sol was aged for $24 \mathrm{~h}$ and a commercial bench grinder (model: ST-150) was used to abrade glass slide having dimension of $10 \mathrm{~mm} \times 60 \mathrm{~mm} \times 1.5 \mathrm{~mm}$. The abrasive glass slide was cleaned by using potassium dichromate and dichloromethane solution, respectively, followed by washing with alcohol and distilled water and then dried at $100{ }^{\circ} \mathrm{C}$ in an oven for further use. The $\mathrm{N}$-doped $\mathrm{ZnO} / \mathrm{CNT}$ nanocomposite thin film (heterostructure) was fabricated by a sol-gel drop coating technique, as follows: first, the $0.4 \mathrm{~mL}$ sol was used drop-wise on a rubbed glass substrate using a pipette. Subsequently, the sol supported on substrate was warmed for $20 \mathrm{~min}$ in an oven at $80^{\circ} \mathrm{C}$ to eliminate the loosely bonded particles from the glass surface. Coated thin film could cover approximately $2 \mu \mathrm{m}$ on the above estimated area of abrasive glass substrate. To obtain the thick film $(\sim 4 \mu \mathrm{m})$, the coating was repeated twice as well as calcined using a muffle furnace (JSMF$30 \mathrm{~T}$, Gongju, Korea) retaining temperature $500{ }^{\circ} \mathrm{C}$ for $2 \mathrm{~h}$. Similarly, the $\mathrm{N}$-doped $\mathrm{ZnO}$ thin film was prepared in the absence of CNT. Finally, pure $\mathrm{ZnO}$ thin film was prepared using the same procedure. A schematic flow diagram for the fabrication of $\mathrm{N}$-doped $\mathrm{ZnO} / \mathrm{CNT}$ nanocomposite thin film by sol-gel drop coating method is shown in Figure 10. 


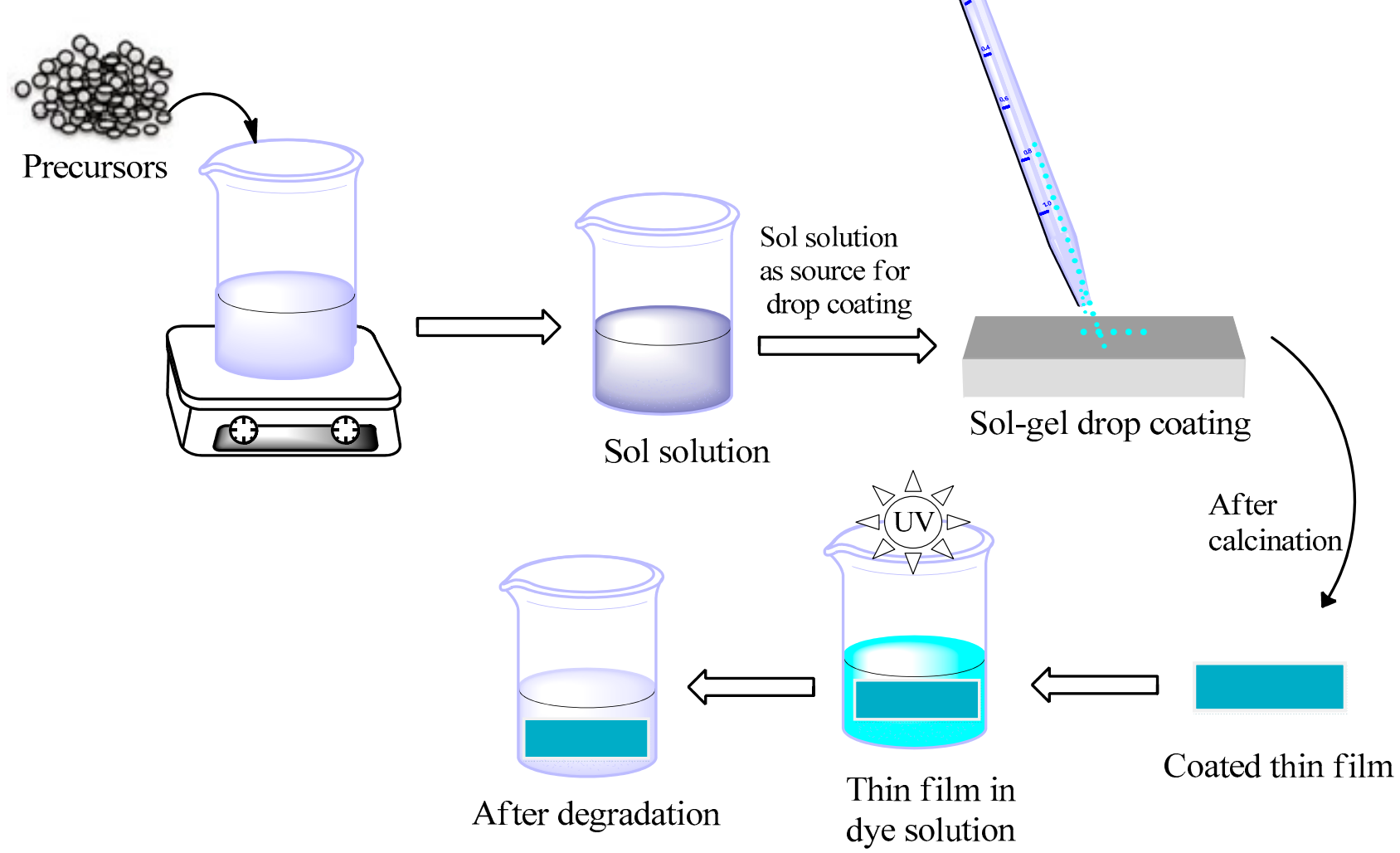

Figure 10. Schematic diagram for the fabrication of $\mathrm{N}$-doped $\mathrm{ZnO} / \mathrm{CNT}$ thin film on glass substrate by sol-gel drop coating process.

\subsection{Film Characterization}

The crystallinity of the prepared thin film was investigated using the XPERT PRO $\mathrm{X}$-ray diffraction (XRD, Almelo, Netherlands) instrument with $\mathrm{Cu}-\mathrm{K}_{\alpha}$ monochromatic radiation source $(\lambda=1.5406 \AA, \mathrm{V}=40 \mathrm{kV}, \mathrm{I}=30 \mathrm{~mA}, \mathrm{RT})$ in the $2 \theta$ limit of $10-70^{\circ}$. The average crystallite sizes of synthesized thin films were estimated with the help of Scherrer equation. The surface morphology and microstructure of synthesized nanocomposite thin films were assessed by the Field Emission Scanning Electron Microscope (FESEM; JSM7600F, Tokyo, Japan). The optical properties of samples were accomplished by double beam UV-Visible spectrophotometer (UV-1800, Shimadzu, Kyoto, Japan). The Fourier Transform Infrared (FT-IR) spectra of the prepared thin films were recorded in transmission mode on $\mathrm{KBr}$ pellets using a spectrometer (Shimadzu IR Prestige 21, Kyoto, Japan).

\subsection{Photo-Catalytic Assessment}

The photo-catalytic degradation efficiency of as-fabricated nanocomposite thin film was determined by measuring the photodegradation of an aqueous solution of MB dye as a target pollutant under visible light and UV light irradiation. The experimental setup is described as follows: firstly, to evaluate photo-catalytic activity of the prepared thin films under visible light irradiation, $200 \mathrm{~mL}$ aqueous solution of $\mathrm{MB}(5 \mathrm{mg} / \mathrm{L})$ and a thin film photocatalyst were taken in a beaker. Then, the beaker containing catalyst was placed in a reactor consisting with a cycled cooling water system to avoid any thermal reaction. In each study, the aqueous solution of MB containing catalyst was initially stirred vigorously for $60 \mathrm{~min}$ in dark to attain adsorption-desorption equilibrium before exposure to visible light (200W tungsten lamp). At given time intervals, the solution was taken from the reaction container with a pipette and the change of residual concentration of MB dye solution was monitored by UV-visible spectrophotometer (UV-1800, Shimadzu, Kyoto, Japan) at 
a characteristics wavelength of $664 \mathrm{~nm}$. The photocatalytic activity of the fabricated thin films over MB dye was analyzed with the help of the following Equation (13):

$$
\text { Degradation Efficiency }(\%)=\left(\mathrm{C}_{0}-\mathrm{C}_{\mathrm{t}}\right) / \mathrm{C}_{0} \times 100
$$

where $C_{0}$ is the initial concentration of $M B$ before light irradiation and $C_{t}$ is the concentration after light irradiation at time $\mathrm{t}$. Similarly, the photodegradation efficiency of thin films photocatalysts under UV light irradiation was carried out by the above-mentioned method using the $60 \mathrm{~W}$ low pressure mercury lamp. The effect of oxidant $\mathrm{H}_{2} \mathrm{O}_{2}$ addition on photodegradation efficiency over MB dye under UV light illumination and thin films reusability were also investigated.

\subsection{Computational Methods}

To investigate the nitrogen doping effect on $\mathrm{ZnO}$, we studied the electronic properties of $\mathrm{ZnO}$ and $\mathrm{N}$-doped $\mathrm{ZnO}$. Consequently, a hexagonal wurtzite structure of $\mathrm{ZnO}$ with the space group $\mathrm{P}_{3} \mathrm{mc}$ and $C_{6 v}^{4}$ symmetry was modeled. The size of supercell $2 \times 2 \times 1$ was considered for 16-atom $\mathrm{Zn}_{8} \mathrm{O}_{8}$. We replaced one oxygen atom by a nitrogen to get $6.25 \% \mathrm{~N}$-doped $\mathrm{ZnO}\left(\mathrm{Zn}_{8} \mathrm{~N}_{1} \mathrm{O}_{7}\right)$. The cell volume and atomic relaxation for both $\mathrm{Zn}_{8} \mathrm{O}_{8}$ and $\mathrm{Zn}_{8} \mathrm{~N}_{1} \mathrm{O}_{7}$ were carried out until the forces on each atom were below $0.01 \mathrm{eV} \AA^{\circ}-1$. The total energy of the system was converged within $10^{-5} \mathrm{eV}$. The plane waves were expanded up to a cutoff energy of $450 \mathrm{eV}$. The Brillouin zone was considered using $4 \times 4 \times 1 \mathrm{k}$-point Monkhorst-Pack mesh. The exchange-correlation interaction in the generalized gradient approximation (GGA)+U method with Perdew, Burke, and Ernzerh of (PBE) function was used for geometry optimization and energy calculation [58]. The effective Hubbard $U$ values 10 and 6 were used for $\mathrm{Zn}-3 \mathrm{~d}$ and O-2p, respectively [59]. We adopted the same $\mathrm{U}$ value of $\mathrm{O}$ for $\mathrm{N}$ atom in $\mathrm{Zn}_{8} \mathrm{~N}_{1} \mathrm{O}_{7}$. The valence electron configurations $\mathrm{Zn} 3 \mathrm{~d}^{10} 4 \mathrm{~s}^{2}, \mathrm{O}_{2} \mathrm{~s}^{2} 2 \mathrm{p}^{4}$ and $\mathrm{N} 2 \mathrm{~s}^{2} 2 \mathrm{p}^{3}$ were considered for pseudo potential construction. All density functional theory (DFT) based calculations were performed using the projector augmented wave (PAW) pseudo potentials, as implemented in the VASP code [60].

\section{Conclusions}

A thin film of N-doped $\mathrm{ZnO} / \mathrm{CNT}$ nanocomposite was fabricated by a low cost sol-gel drop coating protocol and used to achieve photo-catalytic degradation of $\mathrm{MB}$ dye under visible and UV light irradiation, respectively. Experimental results of the XRD and FESEM studies indicated that $\mathrm{ZnO}$ was formed in nano scale successfully without any impurities in the hexagonal wurzite crystal phase. Findings of experimental and computational studies of lattice parameters of prepared thin films with the addition of nitrogen and CNT into the $\mathrm{ZnO}$ crystal do not show any significant differences, which indicate no change of crystal lattice of $\mathrm{ZnO}$. Nearly $100 \%$ degradation of a $5 \mathrm{mgL}^{-1} \mathrm{MB}$ dye solution at neutral $\mathrm{pH}$ was achieved by an $\mathrm{N}$-doped $\mathrm{ZnO} / \mathrm{CNT}$ photocatalyst after $4 \mathrm{~h}$ of irradiation by UV light. The $\mathrm{H}_{2} \mathrm{O}_{2}$ oxidant effect revealed the $100 \% \mathrm{MB}$ dye degradation efficiency for an $\mathrm{N}$-doped $\mathrm{ZnO} / \mathrm{CNT}$ nanocomposite thin film within 60 min under UV light irradiation. The Ndoped $\mathrm{ZnO} / \mathrm{CNT}$ thin film may possibly be reused, which means that the photo-catalytic degradation process could be functioned at a fairly low cost. Overall, the findings in this report can be beneficial and supportive in designing up a scalable and practical way for industrial wastewater treatment.

Author Contributions: Conceptualization, M.N.U. and M.E.; Supervision, M.N.U.; Project administration, M.N.U.; Investigation, M.E. and M.N.U.; Formal Analysis, M.E., J.K.S., M.A.H., and M.N.U.; Methodology, M.E. and M.N.U.; Writing—original draft, M.E. and M.N.U.; Writing—review \& editing, M.E., M.N.U., J.K.S., M.A.H., D.R.S., I.A.S., S.A. and J.U. All authors have read and agreed to the published version of the manuscript.

Funding: This research was funded by (i) Research Center, Shahjalal University of Science and Technology, Sylhet, Bangladesh, grant number: PS/2018/2/17 and (ii) Ministry of Education, Bangladesh, grant number: 37.20.0000.004.033.013.2015. 
Institutional Review Board Statement: Not applicable.

Informed Consent Statement: Not applicable.

Data Availability Statement: Not applicable.

Acknowledgments: The authors are very much grateful to the Department of Chemistry, Shahjalal University of Science and Technology, Sylhet, Bangladesh; Research Center \& Department of Chemistry, Jagannath University, Dhaka, Bangladesh for their administrative and technical support.

Conflicts of Interest: The authors declare no conflict of interest.

Sample Availability: Samples of the compounds are not available from the authors.

\section{References}

1. Sun, H.; Guo, F.; Pan, J.; Huang, W.; Wang, K.; Shi, W. One-pot thermal polymerization route to prepare N-deficient modified g-C3N4 for the degradation of tetracycline by the synergistic effect of photocatalysis and persulfate-based advanced oxidation process. Chem. Eng. J. 2021, 406, 126844. [CrossRef]

2. Li, H.; Li, W.; Wang, F.; Liu, X.; Ren, C.; Miao, X. Fabrication of Pt nanoparticles decorated Gd-doped Bi 2 MoO 6 nanosheets: Design, radicals regulating and mechanism of Gd/Pt-Bi 2 MoO 6 photocatalyst. Appl. Surf. Sci. 2018, 427, 1046-1053. [CrossRef]

3. Liu, X.; Gu, S.; Zhao, Y.; Zhou, G.; Li, W. BiVO4, Bi2WO6 and Bi2MoO6 photocatalysis: A brief review. J. Mater. Sci. Technol. 2020, 56, 45-68. [CrossRef]

4. Kim, S.P.; Choi, M.Y.; Choi, H.C. Characterization and photocatalytic performance of SnO2-CNT nanocomposites. Appl. Surf. Sci. 2015, 357, 302-308. [CrossRef]

5. Akter, N.; Hossain, M.A.; Hassan, M.J.; Amin, M.K.; Elias, M.; Rahman, M.M.; Asiri, A.M.; Siddiquey, I.A.; Hasnat, M.A. Amine modified tannin gel for adsorptive removal of Brilliant Green dye. J. Environ. Chem. Eng. 2016, 4, 1231-1241. [CrossRef]

6. Aman, E.U.M.; Islam, M.F.; Chowdhury, T.A.; Alam, M.S.; Elias, M.; Uddin, M.N.; Samed, A.J.; Hasnat, M.A. An electrochemical analysis of acute contamination of environmental water and restoring of water quality using taro carbon. Appl. Water Sci. 2020, 10, 148. [CrossRef]

7. Moussavi, G.; Mahmoudi, M. Removal of azo and anthraquinone reactive dyes from industrial wastewaters using $\mathrm{MgO}$ nanoparticles. J. Hazard. Mater. 2009, 168, 806-812. [CrossRef]

8. Elias, M.; Akter, S.; Hossain, M.A.; Suhag, M.H. Fabrication of Zn3(PO4)2/carbon nanotubes nanocomposite thin film via sol-gel drop coating method with enhanced photocatalytic activity. Thin Solid Film. 2021, 717, 138472. [CrossRef]

9. Merzouk, B.; Gourich, B.; Madani, K.; Vial, C.; Sekki, A. Removal of a disperse red dye from synthetic wastewater by chemical coagulation and continuous electrocoagulation. A comparative study. Desalination 2011, 272, 246-253. [CrossRef]

10. Torrades, F.; García-Montaño, J. Using central composite experimental design to optimize the degradation of real dye wastewater by Fenton and photo-Fenton reactions. Dye. Pigment. 2014, 100, 184-189. [CrossRef]

11. Sánchez-Sánchez, Á.; Suárez-García, F.; Martínez-Alonso, A.; Tascón, J.M.D. Synthesis, characterization and dye removal capacities of N-doped mesoporous carbons. J. Colloid Interface Sci. 2015, 450, 91-100. [CrossRef]

12. Bhattacharya, P.; Roy, A.; Sarkar, S.; Ghosh, S.; Majumdar, S.; Chakraborty, S.; Mandal, S.; Mukhopadhyay, A.; Bandyopadhyay, S. Combination technology of ceramic microfiltration and reverse osmosis for tannery wastewater recovery. Water Resour. Ind. 2013, 3, 48-62. [CrossRef]

13. Dâas, A.; Hamdaoui, O. Extraction of anionic dye from aqueous solutions by emulsion liquid membrane. J. Hazard. Mater. 2010, 178, 973-981. [CrossRef]

14. Ulson, S.M.D.A.G.; Bonilla, K.A.S.; de Souza, A.A.U. Removal of COD and color from hydrolyzed textile azo dye by combined ozonation and biological treatment. J. Hazard. Mater. 2010, 179, 35-42. [CrossRef]

15. Wang, L. Aqueous organic dye discoloration induced by contact glow discharge electrolysis. J. Hazard. Mater. 2009, 171, 577-581. [CrossRef] [PubMed]

16. Mahajan, N.; Gupta, P. New insights into the microbial degradation of polyurethanes. RSC Adv. 2015, 5, 41839-41854. [CrossRef]

17. Lv, T.; Pan, L.; Liu, X.; Lu, T.; Zhu, G.; Sun, Z. Enhanced photocatalytic degradation of methylene blue by ZnO-reduced graphene oxide composite synthesized via microwave-assisted reaction. J. Alloys Compd. 2011, 509, 10086-10091. [CrossRef]

18. Shinde, S.S.; Shinde, P.S.; Bhosale, C.H.; Rajpure, K.Y. Zinc oxide mediated heterogeneous photocatalytic degradation of organic species under solar radiation. J. Photochem. Photobiol. B Biol. 2011, 104, 425-433. [CrossRef] [PubMed]

19. Zhu, H.; Jiang, R.; Fu, Y.; Guan, Y.; Yao, J.; Xiao, L.; Zeng, G. Effective photocatalytic decolorization of methyl orange utilizing TiO 2/ZnO/chitosan nanocomposite films under simulated solar irradiation. Desalination 2012, 286, 41-48. [CrossRef]

20. Ba-abbad, M.M.; Amir, A.; Kadhum, H.; Bakar, A.; Takriff, M.S. Visible light photocatalytic activity of Fe 3+ doped ZnO nanoparticle prepared via sol-gel technique. Chemosphere 2013, 91, 1604-1611. [CrossRef]

21. Zhong, J.; Li, J.; He, X.; Zeng, J.; Lu, Y.; Hu, W.; Lin, K. Improved photocatalytic performance of Pd-doped ZnO. Curr. Appl. Phys. 2012, 12, 998-1001. [CrossRef] 
22. Rabin, N.N.; Morshed, J.; Akhter, H.; Islam, M.S.; Hossain, M.A.; Elias, M.; Alam, M.M.; Karim, M.R.; Hasnat, M.A.; Uddin, M.N.; et al. Surface Modification of the ZnO Nanoparticles with $\gamma$-Aminopropyltriethoxysilane and Study of Their Photocatalytic Activity, Optical Properties and Antibacterial Activities. Int. J. Chem. React. Eng. 2016, 14, 785-794. [CrossRef]

23. Sakthivel, S.; Neppolian, B.; Shankar, M.V.; Arabindoo, B.; Palanichamy, M.; Murugesan, V. Solar photocatalytic degradation of azo dye: Comparison of photocatalytic efficiency of ZnO and TiO2. Sol. Energy Mater. Sol. Cells 2003, 77, 65-82. [CrossRef]

24. Jongnavakit, P.; Amornpitoksuk, P.; Suwanboon, S.; Ndiege, N. Preparation and photocatalytic activity of Cu-doped ZnO thin films prepared by the solgel method. Appl. Surf. Sci. 2012, 258, 8192-8198. [CrossRef]

25. Chen, C.C.; Liu, P.; Lu, C.H. Synthesis and characterization of nano sized ZnO powders by direct precipitation method. Chem. Eng. J. 2008, 144, 509-513. [CrossRef]

26. Uddin, M.N.; Islam, M.S.; Mazumder, M.M.R.; Hossain, M.A.; Elias, M.; Siddiquey, I.A.; Susan, M.A.B.H.; Saha, D.K.; Rahman, M.M.; Asiri, A.M.; et al. Photocatalytic and antibacterial activity of B/N/Ag co-doped CNT-TiO 2 composite films. J. Incl. Phenom. Macrocycl. Chem. 2015, 82, 229-234. [CrossRef]

27. Uddin, M.N.; Shibly, S.U.A.; Ovali, R.; Islam, S.; Mazumder, M.M.R.; Islam, M.S.; Uddin, M.J.; Gulseren, O.; Bengu, E. An experimental and first-principles study of the effect of $\mathrm{B} / \mathrm{N}$ doping in $\mathrm{TiO} 2$ thin films for visible light photo-catalysis. J. Photochem. Photobiol. A Chem. 2013, 254, 25-34. [CrossRef]

28. Zong, X.; Sun, C.; Yu, H.; Chen, Z.G.; Xing, Z.; Ye, D.; Lu, G.Q.; Li, X.; Wang, L. Activation of Photocatalytic Water Oxidation on N-Doped ZnO Bundle-like Nanoparticles under Visible Light. J. Phys. Chem. C 2013, 117, 4937-4942. [CrossRef]

29. Vaiano, V.; Sacco, O.; Iervolino, G.; Sannino, D.; Ciambelli, P.; Liguori, R.; Bezzeccheri, E.; Rubino, A. Enhanced visible light photocatalytic activity by up-conversion phosphors modified N-doped TiO2. Appl. Catal. B Environ. 2015, 176, 594-600. [CrossRef]

30. Qin, H.; Li, W.; Xia, Y.; He, T. Photocatalytic activity of heterostructures based on ZnO and N-doped ZnO. ACS Appl. Mater. Interfaces 2011, 3, 3152-3156. [CrossRef] [PubMed]

31. Jia, L.; Wang, D.H.; Huang, Y.X.; Xu, A.W.; Yu, H.Q. Highly durable N-doped graphene/CdS nanocomposites with enhanced photocatalytic hydrogen evolution from water under visible light irradiation. J. Phys. Chem. C 2011, 115, 11466-11473. [CrossRef]

32. Xu, L.; Steinmiller, E.M.P.; Skrabalak, S.E. Achieving Synergy with a Potential Photocatalytic Z- scheme: Synthesis and Evaluation of Nitrogen-doped $\mathrm{TiO}_{2} / \mathrm{SnO}_{2}$ Composites. J. Phys. Chem. C 2012, 116, 871-877. [CrossRef]

33. Kadam, A.N.; Dhabbe, R.S.; Kokate, M.R.; Gaikwad, Y.B.; Garadkar, K.M. Preparation of N doped TiO2 via microwave-assisted method and its photocatalytic activity for degradation of Malathion. Spectrochim. Acta Part A Mol. Biomol. Spectrosc. 2014, 133, 669-676. [CrossRef]

34. Shinde, S.S.; Bhosale, C.H.; Rajpure, K.Y. Photocatalytic degradation of toluene using sprayed N-doped ZnO thin films in aqueous suspension. J. Photochem. Photobiol. B Biol. 2012, 113, 70-77. [CrossRef] [PubMed]

35. Elias, M.; Amin, M.K.; Firoz, S.H.; Hossain, M.A.; Akter, S.; Hossain, M.A.; Uddin, M.N.; Siddiquey, I.A. Microwave-assisted synthesis of Ce-doped ZnO/CNT composite with enhanced photo-catalytic activity. Ceram. Int. 2017, 43, 84-91. [CrossRef]

36. Sampaio, M.J.; Bacsa, R.R.; Benyounes, A.; Axet, R.; Serp, P.; Silva, C.G.; Silva, A.M.T.; Faria, J.L. Synergistic effect between carbon nanomaterials and $\mathrm{ZnO}$ for photocatalytic water decontamination. J. Catal. 2015, 331, 172-180. [CrossRef]

37. Silva, C.G.; Sampaio, M.J.; Marques, R.R.N.; Ferreira, L.A.; Tavares, P.B.; Silva, A.M.T.; Faria, J.L. Photocatalytic production of hydrogen from methanol and saccharides using carbon nanotube-TiO2 catalysts. Appl. Catal. B Environ. 2015, 178, 82-90. [CrossRef]

38. Zhu, L.-P.; Liao, G.-H.; Huang, W.-Y.; Ma, L.-L.; Yang, Y.; Yu, Y.; Fu, S.-Y. Preparation, characterization and photocatalytic properties of ZnO-coated multi-walled carbon nanotubes. Mater. Sci. Eng. B 2009, 163, 194-198. [CrossRef]

39. Azqhandi, M.H.A.; Vasheghani, F.B.; Rajabi, F.H.; Keramati, M. Synthesis of Cd doped ZnO/CNT nanocomposite by using microwave method: Photocatalytic behavior, adsorption and kinetic study. Results Phys. 2017, 7, 1106-1114. [CrossRef]

40. Thool, G.S.; Singh, A.K.; Singh, R.S.; Gupta, A.; Susan, M.A.B.H. Facile synthesis of flat crystal ZnO thin films by solution growth method: A micro-structural investigation. J. Saudi Chem. Soc. 2014, 18, 712-721. [CrossRef]

41. Bindu, P.; Thomas, S. Estimation of lattice strain in ZnO nanoparticles: X-ray peak profile analysis. J. Theor. Appl. Phys. 2014, 8, 123-134. [CrossRef]

42. Warren, B.E.; Averbach, B.L. The Effect of Cold-Work Distortion on X-Ray Patterns. J. Appl. Phys. 1950, 21, 595-599. [CrossRef]

43. Delhez, R.; de Keijser, T.H.; Mittemeijer, E.J. Determination of crystallite size and lattice distortions through X-ray diffraction line profile analysis. Fresenius' Z. Anal. Chem. 1982, 312, 1-16. [CrossRef]

44. Ali, A.M.; Ismail, A.A.; Najmy, R.; Al-Hajry, A. Preparation and characterization of ZnO-SiO2 thin films as highly efficient photocatalyst. J. Photochem. Photobiol. A Chem. 2014, 275, 37-46. [CrossRef]

45. Ahmad, I. Inexpensive and quick photocatalytic activity of rare earth (Er, $\mathrm{Yb}$ ) co-doped $\mathrm{ZnO}$ nanoparticles for degradation of methyl orange dye. Sep. Purif. Technol. 2019, 227, 115726. [CrossRef]

46. Park, W.B.; Hong, S.U.; Singh, S.P.; Pyo, M.; Sohn, K.-S. Systematic Approach To Calculate the Band Gap Energy of a Disordered Compound with a Low Symmetry and Large Cell Size via Density Functional Theory. ACS Omega 2016, 1, 483-490. [CrossRef]

47. Fu, J.; Ji, M.; Jin, L. Photocatalytic oxidation of natural organic matter-fulvic acid in water. Chem. Bull. 2005, 68, 871-875.

48. Subhan, M.A.; Awal, M.R.; Ahmed, T.; Younus, M. Photocatalytic and Antibacterial Activities of Ag/ZnO Nanocomposities Fabricated by Co-Precipitation Method. Acta Metall. Sin. (Engl. Lett.) 2014, 27, 223-232. [CrossRef]

49. Sun, H.; Liu, S.; Liu, S.; Wang, S. A comparative study of reduced graphene oxide modified TiO2, $\mathrm{ZnO}$ and Ta2O5 in visible light photocatalytic/photochemical oxidation of methylene blue. Appl. Catal. B Environ. 2014, 146, 162-168. [CrossRef] 
50. Sauer, T.; Cesconeto Neto, G.; José, H.; Moreira, R.F.P. Kinetics of photocatalytic degradation of reactive dyes in a TiO2 slurry reactor. J. Photochem. Photobiol. A Chem. 2002, 149, 147-154. [CrossRef]

51. Tryba, B.; Morawski, A.W.; Inagaki, M.; Toyoda, M. The kinetics of phenol decomposition under UV irradiation with and without $\mathrm{H} 2 \mathrm{O} 2$ on TiO2, Fe-TiO2 and Fe-C-TiO2 photocatalysts. Appl. Catal. B Environ. 2006, 63, 215-221. [CrossRef]

52. Moafi, H.F.; Zanjanchi, M.A.; Shojaie, A.F. Tungsten-doped ZnO nanocomposite: Synthesis, characterization, and highly active photocatalyst toward dye photodegradation. Mater. Chem. Phys. 2013, 139, 856-864. [CrossRef]

53. Yan, Y.; Chang, T.; Wei, P.; Kang, S.-Z.; Mu, J. Photocatalytic Activity of Nanocomposites of ZnO and Multi-Walled Carbon Nanotubes for Dye Degradation. J. Dispers. Sci. Technol. 2009, 30, 198-203. [CrossRef]

54. Liu, W.; Wang, M.; Xu, C.; Chen, S. Facile synthesis of g-C3N4/ZnO composite with enhanced visible light photooxidation and photoreduction properties. Chem. Eng. J. 2012, 209, 386-393. [CrossRef]

55. Ahmad, I.; Akhtar, M.S.; Ahmed, E.; Ahmad, M. Highly efficient visible light driven photocatalytic activity of graphene and CNTs based Mg doped ZnO photocatalysts: A comparative study. Sep. Purif. Technol. 2020, 245, 116892. [CrossRef]

56. Sharma, S.; Mehta, S.K.; Kansal, S.K. N doped ZnO/C-dots nanoflowers as visible light driven photocatalyst for the degradation of malachite green dye in aqueous phase. J. Alloys Compd. 2017, 699, 323-333. [CrossRef]

57. Elias, M.; Uddin, M.N.; Hossain, M.A.; Saha, J.K.; Siddiquey, I.A.; Sarker, D.R.; Diba, Z.R.; Uddin, J.; Rashid Choudhury, M.H.; Firoz, S.H. An experimental and theoretical study of the effect of Ce doping in ZnO/CNT composite thin film with enhanced visible light photo-catalysis. Int. J. Hydrog. Energy 2019, 44, 20068-20078. [CrossRef]

58. Payne, M.C.; Teter, M.P.; Allan, D.C.; Arias, T.A.; Joannopoulos, J.D. Iterative minimization techniques for ab initio total-energy calculations: Molecular dynamics and conjugate gradients. Rev. Mod. Phys. 1992, 64, 1045-1097. [CrossRef]

59. Xu, Z.; Hou, Q.; Guo, F.; Li, Y.; Liu, Y. Effect of strains on the optical and magnetic properties of Ce-doped ZnO with O or Zn vacancies. J. Mater. Sci. 2020, 55, 7390-7402. [CrossRef]

60. Kresse, G.; Furthmüller, J. Efficient iterative schemes for ab initio total-energy calculations using a plane-wave basis set. Phys. Rev. B 1996, 54, 11169-11186. [CrossRef] 